\title{
HISTORY of MINES and PROSPECTS, KETCHIKAN DISTRICT, PRIOR to 1952
}

BY JOHN BUFVERS

DIVISION of MINES and MINERALS DEPARTMENT OF NATURAL RESOURCES STATE of ALASKA 
STATE OF ALASKA

Walter J. Hickel - Governor

DEPARTMENT OF NATURAL RESOURCES

Phil R. Holdsworth - Commissioner

DIVISION OF MINES AND MINERALS

James A. Williams - Director

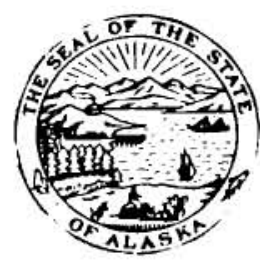

History of Mines and Prospects, Ketchikan Vistrict, Prior to 1952

SR 01

By

John Bufvers

Juneau, Alaska

January 1967 
John Bufvers was born at Buwenas in the Province of Bohuslan, Sweden. He served in a Hussar Reaiment of the Swedish Cavalry and later in the U.S. 14th Infantry during the First World War.

In 1913, Mr. Bufvers mined on the Yakataga beach and White River. He left there for Valdez and the Nelchina stampede and prospected between Thomnson Pass and Beaver Dam in 1914. He worked at the Gold Bullion Mine in 1916, and the Lucky Shot Mine in 1919, both in the Willow Creek District, then at Kennecott's Bonanza Mine in 1919 and 1320, and next at the Beatson Mine on Latouche $\mid s$ land in 1921 and 1322 . He then went south to the Salt Chuck Mine. Prince of Wales Island and worked there in 1925 and 1926 then returned to the Lucky Shot Mine in 1931, and again back to the Salt Chuck Mine during 1.936 and 1937.

Between jobs in these and other areas of Alaska,Mr. Bufvers traveled and orospected. During these times, he visited the mines and prosnects on which he reports in this publication.

In more recent years he was employed by the U.S. Forest Service and the Ketchikan Pulp Company, and now resides in Seattle, Washington.

The information in this sublication is taken from a manuscript written by Mr. Bufvers in the year 1952. Generally, the wording is his. The Division of Mines and Minerals publishes it for its historical value as well as for its general mining and mineralogical background.

\author{
James A. Williams \\ Director \\ Division of Mines and Minerals
}


Salt Chuck

Palmer Cove

Copper Center

Brown and Metzdorf

Haida

It Minc

Poorman

Conner Qucen

Uncle Sam

Rich itill

Pelaska

Hount Andrew

Mamie

Stevenstown Mine

Gold Standard

Keystone

Flagstaff

Independent Copoer

Cascade

Constitution

McGilvery

Lucky Nell

Harris Creek

Georqe

Cracker Jack

Puyallup Mine

Lucky Jim

Dolly Varden

Cunrite

Jumto

Copper Hountain

Conper City

Khayyam iline

lammoth

Moonshine Mine

Hula rula

Crocsus

Valnaraiso $\mathrm{Nine}$

Ciladstone nrosnect

Cymru Conner Mine

ilue ?ird

Gola Stream

Schnenbar Mine

Lon-de-Van

Sed Level line

rino Goo

Cat Island

McLean Arm

lielson \& Tift

icleod Bay

virginia 

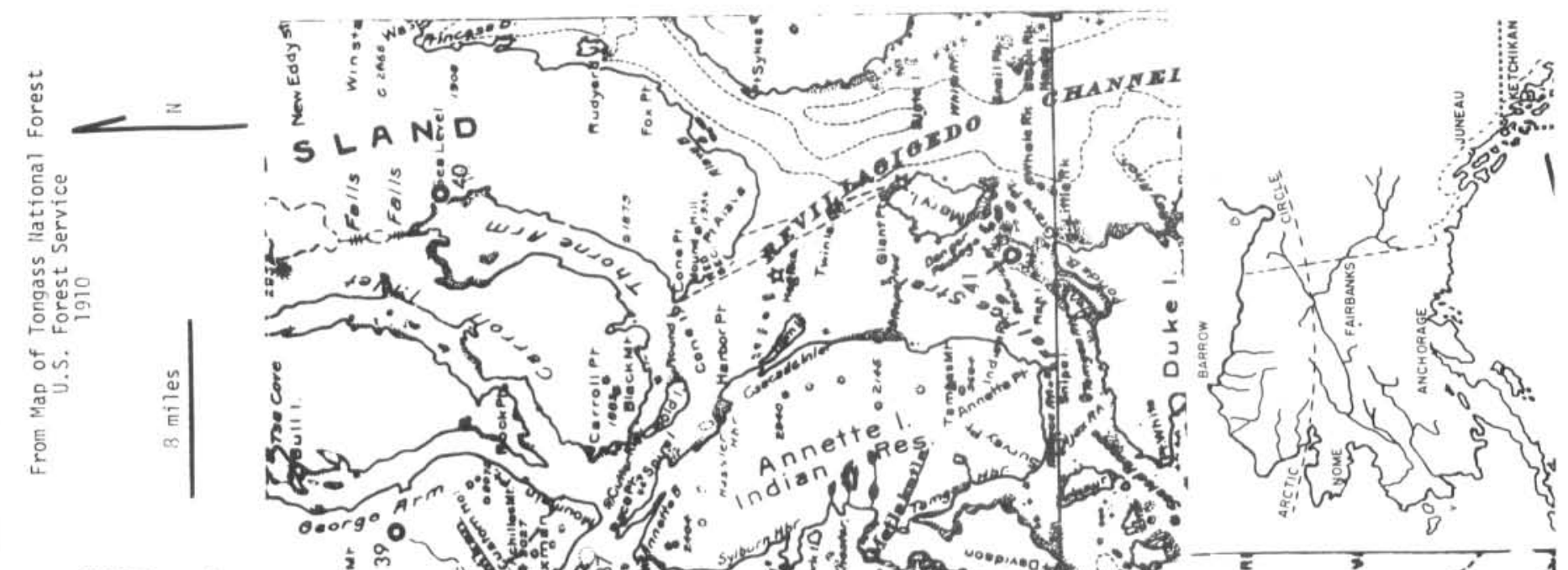

(1)

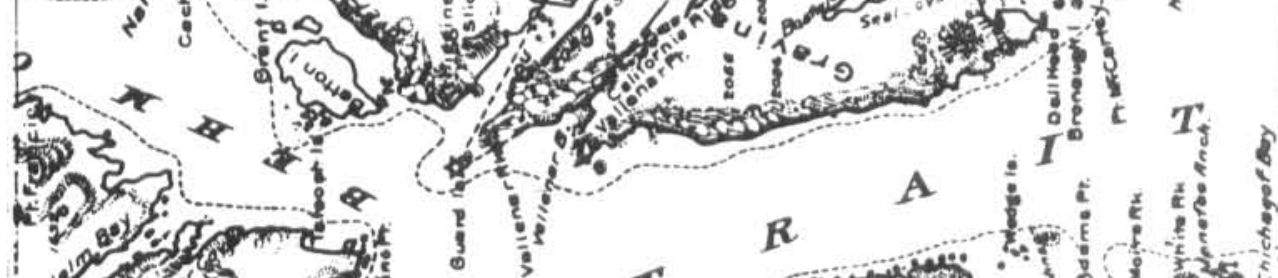

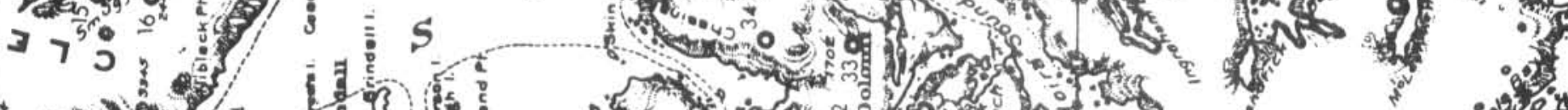

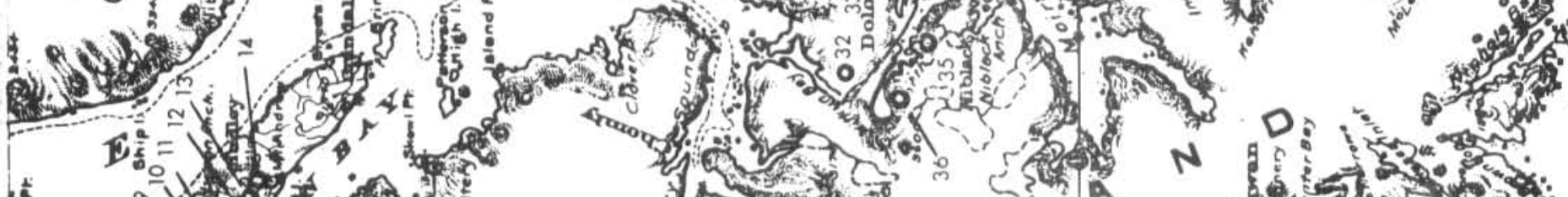

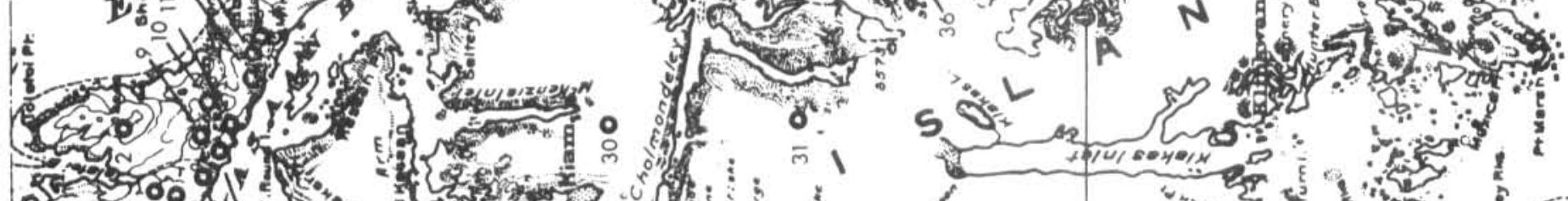
(5ij) 2 I. 5 S

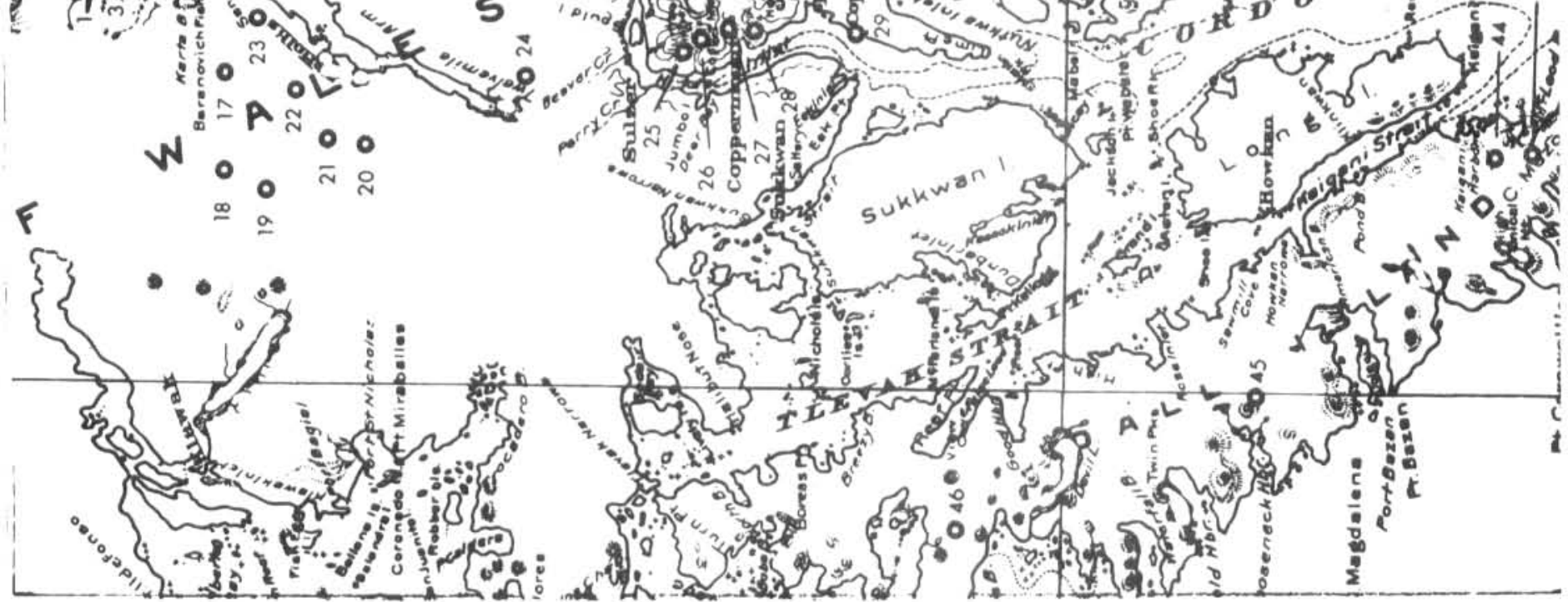


History of Mines and Prospects,

Ketchikan District, Prior to 1952

By

John Bufvers

(1) The Salt Chuck Mine, at the head of Kasaan Bay, and at an elevation of 400 feet, was discovered on August 29, 1906, by Si Goodro and a young fellow by the name of Walter Thomas while they were out hunting. The prospect was originally named the "Joker", but during Goodro's ownership, it was known as the Goodro Mine. A good deal of development was performed by Goodro and ore shipments were sent to the smelter, but most of the development was started after the Alaska Palladium Company took over the property in 1919 with J.E. Chilberg, president. Extensive underground work Dermitted mining of the ore by the glory hole method, and a modern flotation mill of 300-ton capacity was installed. Concentrates were shipped on the motor vessel "Fairbanks" to Prince Rupert, B.C., and from there by railroad to the smelter in Irvington, New Jersey. Due to heavy surface construction in the fall of 1925 , more than 70 men were then on the payroll. Thomas P. Lane was mine foreman and A.L. Howard was in charge of the mill. During 1926, until the mine closed down, Fred E. Pegg was mill foreman.

The valuable metals in the ore were gold, copper, and palladium; consequently, in the fall of 1926 when the price of palladium dropped to less than half of its former value, the operators were forced to close down. About two years later, to satisfy creditors, the mine was sold at a U.S. Marshal's sale for about $\$ 12,000$. It was purchased by the late John Koel of Ketchikan.

In 1929, the Salt Chuck Mine, as it is currently called, was taken over by the Consolidated Mining and Smelting Company of Canada and a large development program was about to be started when the depression forced a shut down.

The Alaska Gold and Metals Comnany with A.L. Howard, nresident and manaqer, took over the mine in 1934, operating it until 1941 when the second World War forced its closure. Arthur J. Theis, a mininn engineer who had sold the Darwin Mine in Southern California to Anaconda Copper Company for a larqe price in 1947, made a deal with Alaska Gold and Metals Company to take over the Salt Chuck Mine and they spent over a year with a crew developing the ground. Because of difficulties arising between Theis and Howard, the mine closed down for the third time in its history.

Si Goodro, before discovering the Salt Chuck, had been prospecting at Dolomi where he found a quartz vein about one mile north of Valaparaiso mill. He built a cabin there and about $1 / 4 \mathrm{mile}$ of corduroy tram road. He had been associated with a prospect in Westward Alaska in the vinciity of Iliamna Lake, which was later named after him. After selling the Salt Chuck Mine, he was reportedly killed during 1920 in an automobile accident near Yakima, Washington.

J.E. Chilberg is still living in Berkeley, California, with his son Hugh, a real estate operator. Ernest L. Adkins went to Wallace, Idaho, as assayer for the Hecla Mining Combany, later moving to Seattle, Washington. He passed away in that city on July 21, 1949, well advanced in years. A.L. Howard died in Seattle, Washington, April 20, 1960 at about the age of 70 years. Thomas P. Lane, a nephew of Charles D. Lane, 
the well-known operator of the Utica Mine in Calaveras County, California, and also of Nome, Alaska, was last heardfrom about ten years ago when he was connected with a mine in the vicinity of Bakersfield, California.

(2) Palmer Cove, on Kasaan Peninsula, halfway between Windfall Harbor and Tolstoi Point, was probably first prospected shortly after 1900 when Antone de Nomie, the Chippewa Indian, and Bradford discovered a copper vein about two miles from the beach. Rich ore was found in a gulch and surface stripping of the vein was done years ago, but the lower end of the vein was found to be cut off by a fault. On the opposite side of the mountain, on the slope towards Kasaan Bay, good-looking float had also been found. One or two small shipments of hand-sorted ore from the Palmer Cove prospect had been made in the past. The vein is about two feet wide and carries good gold values in addition to the copper, but because of the distance from tide water there has been little development.

The late Bill Robinson staked several lode claims near the cove. He was found dead on the beach in the cove in the summer of 1941. Robinson willed his orospect to the Pioneer Lodge in Ketchikan, but the Lodge was unable to take over and develon it.

(3) The Copper Center prospect is located about one mile from tidewater on Kasaan Bay, where the trail to Thorne Bay starts, and about 2000 feet west from the south end of the second lake along the trail. The elevation is about 400 feet. The prospect was discovered in April, 1907 by Mr. Rush, brother to U.S. Rush,one of the discoverers of Rush and Brown mine.

The country rock is mostly greenstone and several shallow shafts and open cuts had been sunk showing magnetite and chalcopyrite over quite a large area, but at only one place has a vein of any size been found. That is about 2 feet in width and traceable in a surface cut for 25 feet. Samples of this vein and from other outcronpings nearby have assayed up to 4 percent in copper and ten dollars in gold.

During the 1930's the prospect was claimed for a number of years by Albert Moquist without any work being performed by him except to spoil the showing of ore in one shaft by blasting muck over it.

(4) The Brown and Metzdorf, also named Shepherd Copper Mine, is located on Kasaan Peninsula, one-half mile north of Mills Bay and about six miles west of Kasaan. The elevation is 310 feet. It was discovered shortly after the turn of the century by William (Billy) Metzdorf and George Brown. Besides copper, the ore carried considerable values in gold. The ore body is a mineralized mass of garnet rock, carrying chalcopyrite and pyrite over a width of ten feet, but as practically all ore above the short tunnel level has been mined out, further development must consist of sinking and it appears doubtful that indications at the mine justify this.

During the 1920's the property was owned by William Shepherd and Charles Dunton, who built an aerial tram to the bay and a small dock. Not getting along very well, the partnership was severed, with Sheoherd acquiring the mine. He disappeared about 1923 and it is believed he went out in the woods and committed suicide.

In 1937 the ground was staked by Erik Lindeman and Nels Ulander. From ore al ready mined they sent thirty tons to the Tacoma Smelter that returned $\$ 40.00$ to the ton. All buildings, the aerial tram and the dock are now collapsed. Of its two 
discoverers, Billy Metzdorf died about 1926 in the Pioneers Home, Sitka. George Brown, in partnership with U.S. Rush, discovered the Rush \& Brown copoer mine. (Picture of Metzdorf in Pioneer Hall, Ketchikan.)

(5) The Haida Mine, also named the Mammoth, is about seven miles west of Kasaan by trail, and Ties on the top of a hill at $500-$ feet elevation. The mine is about one-third of a mile from a sheltered harbor on Kasaan Bay. The property was discovered in the early 1901's by Ed McGann and William Bell. Later the Haida Copner Company was formed in Seattle, Washington, with Freo J. Eitel, president; J.A. Jacobson, vice-president; Victor Vigelius, manager; F.W. Crary, secretary; and J. Albert Johnson, treasurer Uevelopments in 1906-07 consisted of a tunnel about 125 feet lonq, from which a 35 foot raise was run to the surface, and a small glory hole was made by mining some high grade ore at the top. A winze was also sunk from the tunnel for about $30 \mathrm{feet}$. At some time during this work, James Freeburn was in charge.

Later, Billy Metzdorf staked the mine and was able to get enough hiah arade ore for a shipment to the smelter. Returns from the ore shinment were sufficient to enable him to go south and get marricd, but he later returned to Kasaan Bay, alone and broke. According to James Coleman, good ore was supposed to have been struck in the winze.

(6) The It Mine, composed of the Eagles Nest, Alarm and It claims, is located about four and one-half miles northwest of Kasaan and one-half mile from Kasaan Bay. David "Scotty" Nichols discovered the Eagles Nest and Alarm claims in 1906. The It claim, at 600 feet elevation, was staked in 1907 by W.E. Taylor and sold by him to the Sea Island Mining Company for $\$ 10,000$.

During the First World War all these claims were taken over by the Granby Consolidated Smelting and Mining Company and operated with N.W. Sweetzer as superintendent. Large ore bunkers were constructed at the beach and a long dock was built for the loading of ore onto steamers. A large tonnage of ore, carrying good values in both copper and gold, was mined. Since 1918, the mine has been idle. All buildings at the mine camp are now down, the dock is gone, and the ore bunkers, a land mark seen from upper Kasaan Bay, will soon collapse.

N.W. Sweetzer, superintendent at the It Mine, was connected with a number of mines around Ketchikan, the Moonshine being one of them. In 1347, Sweetzer was living in Rosamond, California.

(7) The Poorman prospect, two miles northwest of Kasaan and about 200 feet from tide water, is one of the early locations and was probably discovered by James Coleman. A large body of magnetite, with much chalcopyrite, was developed prior to 1906 when a yo foot tunnel crosscut a 40 foot width of magnetite. A shaft about 30 feet deep was also sunk. A wharf was then built and connected with the mine workings by a surface tram. In 1943, the U.S. Bureau of Mines conducted diamond drilling at the property and more than one million tons of iron ore was indicated. Supplementing the iron content of $50 \%$, the ore also contains copper and a little gold. Coleman disapneared in 1948 and the property is now held by the Coleman estate, Erik Lindeman and A.L. Howard.

(8) The Copper Queen, on Kasaan Bay, was staked in 1857 by Charles Vincent Baronovich and orobablv has the distinction of being the first lode location in Alaska. It is situated a little more than one-half mile east of the Kasaan Cannery. Surface cuts and a shaft are located near the heach and remains of a road bed extend out on the point. The latter is submerged at high tide. The main workings are found near the creek bank at the forks, at 300 feet elevation, and a short distance above the intake of the cannery's water pipeline. 
A short tunnel has been driven in the ore body and about 50 tons of good looking copper ore are on the dump but chances of developing a mine appear slim.

The deposit consists of an irregular mass of chalcopyrite, pyrite, and magnetite. Below the ore dump, in the east bank of the creek, was a 400-foot crosscut tunnel driven years ago to the the ore deposit at depth, but it failed to encounter ore. The portal is now covered by a rock slide. The story is told that Baronovich first saw outcroppings of a vein on Round Island, nearly a mile out in Kasaan Bay, and that, by paddling his canoe in the direction of the vein's strike, he found copper showings on the beach of the bay now named Copper Queen Bay.

The last work at the property was probably done in 1902 at which time it was held by William Bunard who is no longer livinq. The prosoect was later staked by (?) McCue, the first operator of a saw mill and canneryat Kasaan. It is believed he patented the ground.

Joe Baronovich, well-known resident of Ketchikan and former member of the Territorial Legislature, is the son of Charles Vincent Baronovich. C.V. Baronovich was born in Dalmatia, near Trieste. He participated in the gold rush in California and also in the rush to Caribou, B.C. In 1867, he discovered the Cooper Queen. He later operated the salmon saltery and trading post at Kasaan Bay about half way between Sand Bay and Karta Bay. Upon his death, he reportedly gave the trading post to Felix Young of Kasaan. The property was never kept up and lies in ruins, covered with underbrush.

(9) The Uncle Sam copper mine, also named the White Eagle, was discovered in 1899 by Alfred E. Graimes, an Enalishman. It is located about one and one half miles east of Kasaan, above a small island, and at an altitude of 430 to 550 feet. The distance from Kasaan Bay is less than half a mile. Development must have started soon after its discovery for in 1901 an aerial tram to the beach and ore bunkers were built. Ore shipments were made to the smelter in 1906 , returning $\$ 22.00$ to the ton. The ore consisted of a lens of chalcopyrite and pyrite, six to eight feet in width, but practically all the known ore has now been mined out. Considerable magnetite aiso occurs.

(10) The Rich Hill Mine lies at an altitude of 500 feet, a little more than two and one-half miles southeast of Kasaan and almost one-half mile from Kasaan Bay. It was discovered by Henry Andrew. The first real development started in 1917 when the prospect was taken over by Granby Consolidated Mining and Smelting Company.

Several tunnels were driven and the property was opened up for production. An adit was driven underneath the ore body with a raise to the surface and glory hole minina was conducted. From 160 tons of chalcopyrite ore, sent to the smelter by the Granby Company, $\$ 20.00$ per ton was received. Most of the high grade ore has been mined out, but a considerable tonnage of low grade remains. Henry Andrew, discoverer of the Rich Hill Mine, was drowned in March, 1938, when the cannery tender "Alaska Chief" went down following an explosion near Grindall Island. Of the five persons aboard, only Captain Frank Ford of Kasaan was saved. The Rich Hill Mine is now held by Captain Fred Mckay in Ketchikan.

(11) The Pelaska copper prospect, one-half mile in a southerly direction from the head of "Hole in the Wall" at Hadley, lies at an altitude of ahout 500 feet on the west bank of the stream that flows into the bay. It was discovered in the early days by Richard Nuckolls and sold by him for $\$ 700.00$. No large ore body was found. 
At the point of discovery on the hillside, there is an ore dump containing about 50 tons of material mined from the surface, and judging from appearance, this constitutes about all of the ore. Many years ago, a Mr. Wicks owned the prospect, and in the hope of $\mathrm{finding}$ ore at depth, drove a long tunnel through limestone, into the mountain from the valley floor, and also a crosscut, but no ore was found. About that time a large slide destroyed the camp, but no one was killed. The tunnel proved useful even though ore was not found. The corrugated iron ventilation pipes, which had been placed in the tunnel and left there when the work stopped, provided people living in the vicinity of Hadley with their stove pipes; but by 1938 not many were left.

The late Frank Fredricks, who lived for years near the old smelter remains at Hadley, had the prospect staked in 1938. About Christmas of 1939, he committed suicide.

(12) The Mount Andrew copper mine on Kasaan Peninsula is three-fourths miles from Kasaan Bay, at 1400 feet elevation. While coming south from Dawson in 1900 , Samuel Lichtenstadter met a Captain Crooks who described how he had found copper ore in the 1870's when hunting in the vicinity of Kasaan Bay. Lichtenstadter had come north as a representative of a London mining firm and perhaps the reason why he got off the steamer in Ketchikan was because of what he had been told by Captain Crooks. Lichtenstadter, together with F.F. Black, Harry Trimble and Joe Johnson, went to Kasaan Bay where they found outcroppings of ore and named the prospect after Lichtenstadter's backers in England. This must have occurred shortly after 1900. The Mount Andrew I ron and Copper Company was later formed, with Lichtenstadter as its president, and the property was brought into production by that company.

Several tunnels were driven and a large tonnage of ore was mined both by stoping and by the glory hole method. An aerial tram 3,600 feet long carried the ore to bunkers at Mt. Andrew Landing on Kasaan Bay where a dock was built and the ore loaded on steamers and barges for shipment to the smelter.

In October, 1906, the mine got into production with W.C. Freeburn as superintendent, and before the end of that ycar, close to 9000 tons of ore had been sent to the Crofton Smelter in British Columbia. In 1907, about 4500 tons per month went to the smelter. In 1909, a barge, the "Charger" loaded with 3200 tons of ore, sprung a leak and was towed to Karta Bay where it sank. The output of ore diminished and in 1910 only 400 tons were shipped during May, and 1200 tons during June. Evidently the mine closed down in 1911. Mining was resumed about July 1, 1912, with two shifts, and during that summer most of the ore from the sunken barge in Karta Bay was recovered. This ore was the richest mined at the Mount Andrew -- 5.5\% in copper, and some gold and silver. As late as 1942, at low tide, the remains of the barge could be seen in Karta Bay.

It is not known whether the mine was worked during 1913, but on January 1, 1914, mining was started under the direction of W.J. Rogers and the property was surveyed for patent. This was probably the last year that the mine operated. From the fall of 1943 to the summer of 1944, the U.S. Bureau of Mines had a crew at Mount Andrew engaged in sampling of outcroppings and diamond drilling. A large body of iron was found underneath the copper deposit, but whether or not it justifies development is not known to the writer.

Samuel Lichtenstadter, president of Mount Andrew I ron and Copper Company was also interested in the Constitution prospect and other mining properties. He died suddenly 
in his room in the Stedman Hotel in Ketchikan on September 20, 1911. James Freeburn, before coming to the Mount Andrew, was in charge of the Cracker Jack Mine. He later became manager of the Chichagof gold mine. He died about ten years ago.

(13) The Mamie copper mine, one and one-fourth miles south of Hadley at an elevation of $70 \overline{0 \text { feet }}$, was discovered in 1902 by C.W. Fickert. The prospect was named the Mamie after his sailing sloop on which he, at that time, was engaged in hauling freight for the Mount Andrew mine. Because he held a half-ownership in the sloop, Robert Allison was given part ownership in the prospect. Allison later sold out to James Freeburn and Fickert sold to Sam Silverman. Through Silverman, the Brown Alaska Mining Company was formed and named after B.D. Brown, a New York financier who supplied the money for the development of the property. George E. Green was the first superintendent, followed by John Hampson with N.O. Lawson as general manager.

The mine commenced its first shipment of ore in 1904 when 1220 tons went over the 5,500 foot aerial tram to the new smelter in Hadley. In 1905, 12,600 tons were shipped, and in 1907, 30,000 tons. Average values of the ore at that time were $31 / 2 \%$ copper and $0.05 \mathrm{oz}$. in gold.

In October, 1907, mining was closed down. The prooerty was taken over in 1913 by Granby Consolidated Mining and Smelting Company and was probably in operation until the spring of 1917 when Granby transferred its operations to the Rich $\mathrm{Hi} / \mathrm{l}$ and $\mathrm{It}$ mines on Kasaan Bay.

C.W. Fickert, the discoverer of the Mamie, was born in 1865 in New York City. Samuel Silverman, active in the early mining development around Ketchikan, died in Ely, Nevada, in 1933, when 74 years old. His son, Silas S., who was in Alaska and in the Portland Canal district is currently operating a mine near Crown King, Arizona. Stanley Oaksmith, well-known old time resident of Ketchikan, who died in 1950, had been mine foreman at the Mamie and foreman at the Hadley Smelter.

(14) The Stevenstown Mine is above the Mamie Mine on Kasaan Peninsula, at an elevation of $10 \overline{00}$ feet, and was found in 1902 by Chris Aus and sold by him to Sam Silverman. The prospect was later taken over by Hadley Consolidated Copper Company with Sam Silverman, president and George E. Green as mine superintendent. Development started in June of 1905 and the ore was sent first over a 700-foot surface tram down the hill to the Mamie Mine and from there by aerial tram to the Hadley Smelter. A trail one mile long led down the south side of the peninsula to Boggs Landing on Kasaan Bay. For the first two months the daily output of ore was 50 tons, but later it increased to 100 tons. Up to January 1, 1907, the mine had produced 35,000 tons of ore having an average value of 74 pound copper, $\$ 1.00$ in gold and 20 cents in silver per ton. The flat-lying ore body was pretty well mined out when the mine closed down on July $1,1907$.

In February 1944, Louis Stick and the writer went through the main haulage tunnel, 550 feet long, which penetrates the ridge between the Mount Andrew and the Mamie Mine and passes underneath the Stevenstown ore deposit. At that time, it appeared that several of the old loading chutes made of heavy planks could still be used.

(15) The Gold Standard Mine on the west side of Helm Bay was discovered in September, 1897, by Thomas F. Johnson (Helm Bay Johnson) and C.F. Dyer. A rich quartz 
outcropping of free milling ore wasfound half a mile from the beach and about $\$ 20,000$ in gold was taken out in a short time by grinding the ore in an arrastre.

Later work included a shaft sunk at 225 feet elevation to a depth of 150 feet from which drifts were extended, and a few short tunnels driven from the surface. A 5-stamp Risdon mill was installed in 1899 and run by water power. The mine was in production intermittently for a number of years.

The country rock is greenstone schist in which two systems of quartz veins occur. The older, which are large veins, strike parallel with the schistosity and dip $60^{\circ} \mathrm{N} . E$.; the younger veins follow the trend of the former, but dio $60^{\circ}$ to $70^{\circ}$ S.W. The principal vein deposit, which is developed by the shaft, is of the older system and varies from six inches to six feet in width. About half the values were in free gold. Production is reported to have been close to $\$ 200,000$ and a selected shipment sent at one time to the Copper Harbor smelter yielded a return of $\$ 500.00$ per ton.

An old newspaper item mentioned Thomas Appleton and C.L. Parker of Seattle, Washington, as stockholders in the old company, in addition to Johnson and Oyer.

After lying idle for some time, the mine was staked by Richard Nuckolls, and about the same time a prospect at the beach was also staked. Later a long tunnel was driven underneath the beach outcropping and two raises were run to the surface to permit mining by the glory hole method. The stamp mill was also moved to the beach and a long flume built to carry water to an overshot wheel for power.

Most of the mining at the new Gold Standard on the beach was done by persons holding short term leases on the beach deposit. Consequently, the oroderty never received the development that might have proved its merits. Holders of short term leases could generally be expected to do nothing other than mine out the easily available ore. Parties willing and able to conduct exploration were discouraged by the owner's insistence that a certain tonnage of ore be milled regularly. A biq company taking over the mine would have spent a year or so concentrating its efforts on underground development and the proving of ore reserves. However, the owners were princidally concerned with the small royalty received from the daily milling of about 15 tons of ore and they seemed unable or unwilling to look ahead.

From 1923 to 1925, the mine was leased to Charles Dunton and Albert Selin, and in 1926 to Ashely Egtvet and John Bufvers. Another later leaser was James Freeburn who extended the tunnel considerably, but disagreements with the owners finally resulted in his leaving. A partnership group consisting of Anton Wilson, John Folwartzny, Carl Helm, Ed and Gus Johnson, also operated the mine for a time.

For perhaps a year or two the pronerty was held by Homer Tilly of Tacoma, Washington, with Clayton L. Leeds as foreman. During this time the old Gold Standard was pumped dry, but very little ore was found in the old workings. The last operator of the mine, John folwartzny, continued until 1941 when he quit and the property has been idle since. Probably most of the ore above the tunnel level has been mined out, but a good sized ore body might exist below the tunnel; however, sinking will be necessary in further development. 
Dick Nuckolls and Dr. G.E. Dickinson have been co-owners of Gold Standard for the last thirty years. Both are residents of Ketchikan district since the early days.

"Helm Bay" Johnson, a grand old man, always pleasant and courteous, died in Ketchikan on November 11,1942 at the age of 82.

(16) The Keystone prospect, about two miles from the head of Smugglers Cove, at about 675 feet elevation, was under development in 1902, with J.A. Bradley of Dubois, Pennsylvania, in charge. The ore body consisted of wide stockworks of stringers in a schist belt, with much pyrite and some gold and silver. Mine workings, consisting of a cross cut tunnel and shafts, totaled about 700 feet in length. Also, a $65-$ foot shaft was sunik. The property has been idle now for half a century.

Bradley died in Ketchikan on May 9, 1902 from injuries received when his boat was wrecked on the rocks at the north end of Betton Island in Behm Canal.

(17) The Flagstaff Mine on the northeast slope of Granite Mountain, about four miles southwest of Karta Bay, was discovered about 1900 by Antone de Nomie, a Chippewa Indian, probably from Minnesota. Several veins outcrop on the pronerty from elevations of 1400 to 2400 feet. It is believed that the first development was financed by a Dr. Guthrie, but the early history of the mine is not remembered by anyone now living in the reqion.

In 1925, Tom Stevens owned claims on the south side of a tributary of Granite Creek. On the north side of the stream William Shepherd had staked claims, but later Stevens owned all the ground. About 1931, Mrs. Bia Annette grubstaked Tom Stevens and received half interest in the property. In 1937, the ground was taken over by the Flagstaff Mining Company, William M. Goodwin, president and manager. Interested in the company were D.S. and C.B. Morgareidge of Ten Sleep, Wyoming, and Henry J. Mesta and George W. Sherican of Pittsburgh, Pennsylvania, both connected with an eastern steel corporation.

The Flagstaff Mining Company constructed a two-mile truck road from Karta Lake, up Granite Creek, to an elevation of 510 feet where the mining camp was located and a 20-ton mill erected. The old main tunnel, at 1400 feet elevation, was extended in on the vein to a total length of $1120 \mathrm{feet}$, and a considerable tonnage of ore was mined and sent to the mill over the 1800-foot aerial tram. A 55-foot winze was sunk with the bottom in ore.

In the main level, the vein is as much as 40 inches wide, but it averages about 20 inches. Six hundred feet above the main tunnel, the vein is four feet wide and well mineralized. There are also other veins that have not been explored. Minerals in the main vein include galena, chalcopvrite, pyrite, sphalerite, covellite, and chalcocite. Experimental ore-testing would probably be required to determine a proper and efficient mill recovery method. Failure to recover a large part of the gold in the mill was the reason given for closing the mine in 1941 .

As the mine has only been developed on one level it may at some time in the future be taken over by persons financially able to extend the main level and explore some of the many other outcroppings, and perhaps develop a real large producer. 
Antone de Nomie, the man who discovered the Treasure prospect, as the Flagstaff was first called, came to Valdez in 1090 in the emnloy of a Major Baldwin from Minnesota. He then joined the rush into the interior of Alaska by way of the Copper and Tanana Rivers. He also spent a little time around Whitehorse before coming to Southeastern Alaska.

In partnership with (?) Bradford, Antone de Nomie also discovered a copper showing about one and one-half miles back of Palmer Cove. Palmer Cove lies about four miles north of Windfall Harbor. Moving later to the Portland Canal district, he there located the Indian Mine, which after many ups and downs, was finally, in the early part of 1951 , put into production after the owners were joined in the development by the nearby, wellknown, Silback Premier Mine. What became of de Nomie after he left Portland Canal is not known. According to old timers, he had a reputation of beina able to cover much qround when out prospecting.

An arrastre, near the altitude of 2500 feet on Granite Mountain, was built around 1310 by ben Leibrant, an expert on that kind of mill and a well-known prospector. Leibrant is now living in retirement near Maple Falls, Washington.

Ton Stevens, mentioned in the discussion of the Cascade Mine, and the Flagstaff Mine staked for many years. He was a tyoical orospector of the breed that, in years none by, roamed the western hills, and by their discoveries helped to make the west as it is today. Tom was never downhearted and always ready to take a chance. There are few prospectors like nim today. Tom Stevens' children lacked their father's interest in mining and the Flagstaff Mine is now owned by Mrs. Bia Annette and her son Kenneth, both of Ketchikan.

(13) The Independent Copper prospect is one and one-half miles west of Kasaan and was discovered by either Joe llahoney or Ed McGann. Early development consisted of stripping overburden from tir: outcrop, sinking a short shaft and shipping a little ore. The nartnershin durinr this work was composed of Mahoney, Mcfiann and James Coleman, but it did not survive long because Coleman was a difficult personality and his two partners walked away leaving the orossect to him.

since that time, no work has been done at the nrospect except for a few diamond drill holes drilled in $1 ; 43$ by the U.S. Bureau of Mines. The drilling proved the ore bndy to be but a shallow capping. The ore, mostly of chalcopvrite, would make good mill feed, but is too low for shinping. Samples taken by the writer in 1936 assayed as follows:

$\begin{array}{lllll}\text { Across } 4 \text { feet, } & \text { gold } 0.42 \mathrm{oz} . & \text { silver } 4.40 \mathrm{oz} . & \text { copper } 5.43 \% \\ \text { Across } ; \text { feet, } & \text { gold } 0.28 \mathrm{oz} . & \text { silver } 3.80 \mathrm{oz} . & \text { copper } 2.91 \% \\ \text { Across } 6 \text { feet, } & \text { gold } 0.10 \mathrm{oz} . & \text { silver } 1.40 \mathrm{oz} . & \text { copper } 1.55 \% \\ \text { select sample, } & \text { gold } 0.44 \mathrm{oz} . & \text { silver } 2.10 \mathrm{oz} . & \text { copper trace }\end{array}$

Considerable magnetite is also present.

Joe Mahoney was born in Michigan in 1873, and after coming to Ketchikan he spent his life as a miner and prospector. The Mahoney Mine at George Inlet was discovered by him before 1905 and he was found dead in the cabin there about March 1, 1940.

Ed McGann, Mahoney's partner, both in the Independent and George Inlet prospects, died in Ketchikan in 1929 at the age of 61 . 
James Coleman, a blacksmith and drill sharpener by trade, had been employed in many of the early mines around Kasaan Bay. He discovered the Poorman Mine, two miles west of Kasaan and about 3000 feet north from tide water sometime before 1905 . Coleman lived in a cabin at the mouth of Poorman Creek, two miles from Kasaan, and he disappeared in November, 1948. He had gone to Kasaan for his mail and on his way home had left his packsack and kerosene jar about 1000 feet east of the $11 / 2 \mathrm{mile}$ post. Probably he became tired walking the trail and went down to the beach where he died. High tides may have carried his body away.

(18) The Cascade Mine at 1300 feet elevation and close to four miles in a southwest direction from Hollis, Prince of Wales Island, was discovered in either 1900 or 1901 by Richard Nuckolls when he found high grade quartz float in the creek below the falls. Because of the rich showing at the surface of the vein (assaying more than $\$ 200.00$ to the ton), the prospect soon afterward sold to Sam Silverman for a cash down payment of $\$ 10,000$. Silverman, a prominent mining man, was the head of Brown Alaska Mining Corporation, which operated Stevenstown Copper Mine and Hadley Smelter on Kasaan Peninsula.

First work at the prospect consisted of running an open cut along the two-foot wide vein from the southwest bank of the creek, and the ore taken out was sacked for packing to Hollis, and the haul by boat to the Hadley Smelter. As a road was never built to the Cascade Mine, the cost of transportation was very high for which reason, and perhaps for others, all work was suspended by Silverman after about two years. Later the prospect was staked by different parties and in 1913 and 1914, it was held by Charles Radenbaugh, who packed in a small two-stamp mill that was run by water power, but the ore in depth turned into base and amalgamation was unable to catch the gold and the operation did not pay. Jake Leibrant also had the ground staked in the early days. In 1931 the property was staked and held for some time by Tom Stevens, a well-known miner and prospector. It was again staked, around 1938, by James Matuska, now of Juneau.

Few persons would have tackled the job that Matuska took on as he went to the expense and hard work of packing in a five-ton ball mill, crusher and concentrating table, of course, all sectionalized, but still a difficult job because of the poor trail. Also 250 feet of seven-inch wooden pide, in eight-foot lengths, was taken in because the mill was to run by water power. At the beginning of the second World War, Matuska had his mill set up ready to grind the selected ore he had mined, but because of government objections to gold mining, he left to work for the government on Annette Island. Returning after the war, he found that a snow slide had carried away the mill. The property is still held by Matuska, but his plans for the future are not known.

In the early days a draft was run on the vein for 175 feet, showing an average width of two feet. This drift is located across the creek from where trenching of high grade ore was done. Metallic minerals are pyrite, zinc blende, galena, and gold, with quartz and calcite gangue. The vein strikes N. $53^{\circ} \mathrm{W}$., dips $70^{\circ} \mathrm{S} . \mathrm{W}$. , and by trenching, it would perhaps be traced a longer distance up the hill.

A crosscut tunnel was driven in the early days for 300 feet to undercut the vein below the draft, but was not advanced far enough -- about 100 feet more might have cut the vein. 
Richard Nuckolls, the discoverer, known to everybody as Dick, was born in Gambetta, Virginia and died in Ketchikan, July 8 , 1943, almost 84 years of age. Before coming to Southeastern Alaska, he had prospected in Lower California, Mexico and in Alaska -the Copper River region, before Cordova was on the map -- and also in the Nabesna and Mentasta Pass areas. Charles Radenbaugh also had located the Snow Drift prospect one and one-fourth miles east of Cascade, but ore samples from that place assay low. Radenbaugh died many years ago. Jake Leibrant, living at his homestead near Mile $21 / 2$ west of Kasaan, disappeared in 1928 and Tom Stevens died in 1938 at the age of 84. (Picture of Stevens in Pioneer Hall, Ketchikan).

(18) The Constitution prospect on Prince of Wales Island is situated about seven miles by trail up McGilvery Creek Valley in a southwesterly direction from the west end of Salmon Lake, at an altitude of 2000 feet. In a small stream on the hillside facing the south, and three-fourths of a mile north of McGilvery Creek, a tunnel has been driven on the vein for 130 feet. Probably the prospect was first located by finding quartz float in the stream, as the writer did years later. At the portal, the vein is four feet wide, but in the face of the tunnel, it has narrowed to five inches aad appears to be cut of $f$. Below the tunnel, the writer, in June, 1933, uncovered the vein for a distance of 200 feet. Average width was one and one-half feet, and average values around $\$ 20.00$ in gold to the ton. In the tunnel, the vein strikes $\mathrm{N}$. $65^{\circ} \mathrm{W}$., with the dip varying from vertical to $60^{\circ} \mathrm{S} . \mathrm{W}$. Ore minerals are pyrite, chalcopyrite, galena, and zinc blende filling a shear zone in gabbro and amphibolite.

The Constitution prospect was discovered in 1900 by Dave "Scotty" Nichols, and soon afterwards, it was taken over by Sam Lichtenstadter, a well-known mining promoter of that time. Before 1905, the above-mentioned tunnel had been driven and also a shorter one higher up. Reportedly, Burkenheimer and Hicks, a shoe manufacturing concern in San Francisco, financed most of the work done. As the distance to tidewater at Karta Bay is close to $15 \mathrm{miles,} \mathrm{the} \mathrm{cost} \mathrm{of} \mathrm{freighting} \mathrm{supplies} \mathrm{was} \mathrm{prohibitive} \mathrm{and} \mathrm{for}$ that reason, development was stopped.

In 1907, the prospect was restaked by Richard Nuckolls, and it then remained idle until June, 1932, when it was staked by W.L. Philbrook and the writer. In the years between 1907 and 1932, the prospect had become a "lost mine" and several persons had been looking for it without any luck. The lower tunnel is approximately 3000 feet south from the top of the ridge. Sawtooth Mountain is not much more than a mile west from the ridge above the prospect.

Scotty Nicholls also discovered the Eagles Nest group of claims on Kasaan Peninsula and spent much of his time prospecting that region. He died in Ketchikan on November 2 , 1937, at the age of 65 . Philbrook, with a reputation as one of the best cooks in Alaska, died about 1948.

(18) The McGilvery prospect, probably first slaked on July 26, 1903, by Michael McGilvery and named the Blackbird (in the early days it was also known as the Independent) is situated at the head of McGilvery Creek, a southwesterly tributary of Salmon Lake. The distance from the lake to the prospect is about nine miles.

At an elevation of 1300 feet the vein is one foot wide, while higher up the mountain the width is two feet. Ore minerals are galena, pyrite, and zinc blende, the country rock being slate and graywacke. The vein strikes $N$. $75^{\circ} \mathrm{W}$., and dips 
$75^{\circ}$ S.W., has free walls, and occurs along a shearing plane in altered porphyry (andesite), which is included in a generally much altered sedimentary complex. The prospect was discovered around 1900 by Mike McGilvery who died about 1915.

According to rumor McGilvery had very rich ore and brought gold with him every time he came in to Ketchikan, but this story might be debatable. Following McGilvery's death in 1915, no one visited the prospect until 1934 when it was visited by Erik Lindeman and Nels Ulander. In 1945 the prospect was staked by Victor Hautop, but the ground is now open. Across the mountain from the McGilvery property, at the head of the north fork of Harris Creek, mineralized veins have teen found. Should a road ever be built up the North Fork, and mining there uncier taken, then perhaps a tunnel might be driven into the ridge that separates McGilvery Creek from the North Fork and then the old prospect could easily be mined.

Snowslides occur frequently in the vicinity of McGilvery prospect. In the spring of 1933, when the writer was prospecting the Constitution, two miles away, the heavy thunder of snow slides could be hearc about noon each day. On the north side of McGilvery Creek, near the head, is the Sawtooth Mountain which can be seen from upper Kasaan Bay and from Twelve Mile Arm in front of Hollis. The great height and steep sides of the mountain completely dwarf the narrow valley of McGilvery Creek at its head.

(19) The Lucky Nell Mine, discovered on May 29, 1900, by George Gervais and William Crowell, is situated about seven and one-half miles northwest of Hollis at an elevation of from 1450 to 180 feet.

Gervais had worked in copper mines at Butte, Montana, and came to the west coast of Prince of Wales Island for the purpose of looking for gold in the river tilat flows from Klawak Lake. Not finding any placer gold, Cervais moveu to the east end of the lake on a raft and prospected up the valley of the north fork of Harris Creek where he found the Lucky Nell vein. Later in the same year the upper extension of the vein was staked as the Commander group by Gervais, W.N. (Bill) Lynch, and Captain H.N. James.

In 1902, all the claims were sold to an English syndicate for $\$ 87,000$ but, as only part of the purchase price was paid, the property later reverted to its original owners. Between 1900 and 1910, five adits were driven on the vein at several elevations.

W. Crowell sold his interest in 1910 to a Mr. Brown of New York City (Derhaps Brown Alaska Mining Company of Hadley), but something apparently happened to this deal as that share in the property was later staked by Gervais. W.N. Lynch died about 1913 and Captain James passed away in 1909.

In a survey of the mining industry around Ketchikan in 1914, Emil E. Huria mentioned that the Lucky Nell was then owned by George Gervais, and his brother Fred Gervais. The Commander groups of claims was owned by Gus Detlifson.

A shipment of 30 tons of ore from the Lucky Nell, sent to a smelter in the spring of 1914 went $\$ 46.00$ per ton and netted $\$ 33.00$ per ton after smelting and freight charges had been paid. 
Early development consisted of building a road between Hollis Bay and the mine but the roadbed was too soft for pack horses and wagons. Shipments were probably hauled on sleighs in the winter. At various elevations, almost 1000 feet of drifting on the vein was done by hand drilling. A raise connects the 550-foot long main level with the next drift above. A 25-foot winze from the main level was sunk for 25 feet in two and one-half feet of good ore. In 1934, Colonel E.J. Ryan of Vancouver, B.C., took over the Valiparaiso Mine at Dolomi and he wanted information about the Lucky Nell. On November 8, Ryan, George Gervais and the writer left Hollis for the mine spending one and one-half days there. Assay results from samples taken by the writer were as follows :

Lower tunnel: two samples, one from the dump; the other, 20 feet inside the portal-average value $\$ 1.33$.

Main tunnel: six samples, average width 32 inches-average value $\$ 19.30$.

Dump, outside main tunnel: one sample - $\$ 22.00$.

No. 3 tunnel: two samples, average width 30 inches - average value $\$ 44.92$.

No. 4 tunnel: three samples, average width six inches - average value $\$ 9.34$.

These samples comprised a preliminary sampling of the possibilities of the property; weather conditions prevented taking samples above the No. 4 tunnel. At several places above the No. 4 tunnel, the vein is much wider than six inches and above the upper tunnel, at 1825 feet elevation, it is four feet wide.

Colonel Ryan sent the writer to the mine in the spring of 1935 to get markings and the camp in condition for arrival of examining engineers. The writer, going inside No. 2 (main) tunnel, found a muck pile covering the face. The tunnel had been driven a distance of 500 feet on the vein and I realized that the engineers would want to see how the vein looked in the face of the tunnel. Consequently, had the muck shoveled back from the face and then found the reason for the muck pile. The vein was faulted. Having two extra men with me and plenty of time, I decided to do a little exploring by crosscutting and soon found the vein again. That, of course, made the ore outlook on that level favorable. Afterwards when asking Gervais if he believed he could have fooled an engineer on examination by hiding the face by muck, he only gave a foolish grin. Probably it never occurred to him that such a muck pile in the face of the tunnel would look very suspicious.

In June, two engineers arrived, Louis Levensaler, representing Seattle parties whom Colonel Ryan had contacted, and John F. Galloway, consulting engineer for Colonel Ryan. A very thorough sampling was made of all underground workings and surface exposures. Evidently the examination was favorable for in the fall of that year, Colonel Ryan intended to send a crew to the Lucky Nell. Suddenly, however, all work at Dolomi closed down when the Colonel had differences with his financial backers. Consequently, there was no work done at the Lucky Nell.

About 1942, Gervais realized that he was getting too old to climb back and forth to the mine so he took James Matuska in with him as part owner of the mine. Later he sold his interest to a relative in the state. In the winter of 1944-45, Matuska made a deal whereby Homer Tilly of Tacoma, Washington, secured an option to purchase the property for $\$ 75,000$. The Lucky Nell Mining Company was organized and close to $\$ 100,000$ was raised from business and professional people. 
The first work was done on the old road, but in place of graveling the road, starting at the beach, the work consisted merely of clearing the road and making it passable for a tractor. As a result, it soon became a mud hole. The company, expecting to get the property in production almost immediately brought in a used 15ton ball mill, together with compressor, crusher and other equipment, but because of the poor road it never reached the mine and was unloaded at different places along side the road to rust away.

George Gervais died in Ketchikan in 1945; when 78 yearsold. His younger brother Fred, a heavy drinker, died many years ago on the trail near the Forest Service bridge across Sun-in-Hat Creek, one and one-fourth miles west of Kasaan. While intoxicated he had left the mailboat at Kasaan and traveled up the trail, never to be seen again. His skull was found later near the bridge and placed on top of a stump, but it has since disappeared.

William Crowell, the other partner in the discovery of the Lucky Nell, also died many years ago.

Captain Henry $N$. James, one of the Commander group discoverers, spent his last years on his homestead two and one-half miles from the beach on the north side of Maybeso creek. James had the reputation of being a hard man, and $i t$ was rumored that before coming to Hollis, he had been a member of Soapy Smith's gang in Skagway. He died in May, 1909, when 70 years old, and was buried at Hollis Bay where the road to the Lucky Nell Mine begins. Gus Detlifson also passed away many years ago.

(20) The Harris Creek Mine is about two and one-half miles from Hollis, Prince of Wales Island, on the north side of the creek, three-fourths miles from its mouth. Different stories have been told about its discovery. Ben Leibrant said that he first found the vein in the creek and took samples from the outcropping to Bill Harris, an old prospector. Harris looked at the samples for a minute and then threw them away in the brush saying they were no good. Leibrant, then being a young fellow and green at prospecting, believed Harris and did not stake his find. This occurred around 1900 and soon afterwards the vein was staked by B.F. Redman and named "The Julia" for his wife. About a year later, the prospect was sold for $\$ 1,000.00$ to Bob Allison, John Stedman and C. Whitney. However, the new owners accomplished no work and the ground reverted to the public domain. It was then staked a second time by Redman and soon sold to Charles Dunton for $\$ 300.00$.

Before coming to Harris Creek, Dunton had been working at the Valparaiso Mine at Dolomi. He was an experienced miner and an expert in building arrastres, and the first real development of the property was performed by him. The shaft was sunk by Dunton, a stamp mill installed and, for a number of years, the mine operated and became known as the Dunton Mine.

A 1905 U.S.G.S. report stated that the inclined shaft was 200 feet deep and, at the 50, 100, and 150-foot levels, drifts had been extended for 35 feet on the $50-$ foot level and 80 feet on the 100-foot level. The ore shoot was about 60 feet long and from two to five feet wide and had high value in gold, 50 per cent of which was free milling. 
In 1914, the Julia claims and Humboldt group, situated on the hillside north of the shaft, were owned by M.K. and J.H. Rodgers, but leased to Mat thew Reese and Harry Webber. Previously, M.K. Rodgers had directed the opening up of the Hidden Creek Copper Mine near Observatory Inlet, B.C., taken over about 1911 by Granby Consolidated Mining and Smelting Company. Anyox Smelter was later built there. Mat thew Reese held the lease on the Harris Creek Mine alone during the First World War and he found and mined out a rich pocket, worth $\$ 10,000$, in the workings below the creek. Reese installed a 50-ton ball mill purchased from the Salt Chuck Mine and did much to put the property in better operating condition.

Joseph Henry Rodgers in 1922 moved to Colorado and became a leading geologist of that State where he died in Boulder, April 23, 1952. He was a part owner of the Slide Mine at Gold Hill, Colorado. His brother Myron was associated with him in the early development at the Hidden Creek Mine, Anyox, B.C.

About 1923, the mine was taken over by the Kasaan Gold Mining Company and among its most prominent stockholders were Sidney Orake, H.D. Larned, W. Updike, and the secretary F.H. Knowlton, all of Seattle, Washington. Jerry Walker, a lumberman of Hoquiam, Washington, and T.L. Moore, mineral surveyor of Mt. Vernon, Washington. W.J. Elmendorf was consulting engineer.

A large sum of money was spent developing and equipping the mine. Except for a shutdown in 1925, production from the shafts and six levels continued until January, 1929. Because of the graphite in the ore, a poor recovery of gold was made and both cyanidation and flotation was used.

The Humboldt tunnel, on the hillside north of the shaft, was driven a long distance to get beneath the old George prospect on which good ore had been found. With only a little more than 100 feet to go, the Kasaan Gold Company closed down in January of 1929.

In April 1926 on the writer's first visit to Hollis, the mine was closed down with only a watchman by the name of Freeman there. Went with him underground to the deepest level on 300 and found all workings pumped dry. At that time a new road had been constructad by the Territory to the mine starting on south side of the bay where Harris Creek flows out and with bridges over both Indian and Harris Creeks. When the mine reopened, about a year later, A.L. Howard became superintendent, but after a year resigned and his place was taken by Harold Hales.

(20) The George prospect was discovered in 1903 by James Bawden who gave it to Bill Harris. It was later owned by Dr. Henry C. Story and Big Gus Detlifson of Ketchikan. About 1923, the prospect was staked by 0liver Davis, a well-known wood cutter, and in 1926 Kasaan Gold Mining Company purchased the prospect from Davis for $\$ 1,500$. However, the company closed down before it had time to open up the prospect. $0 . K$. Hillman, a miner working for the company, spent his evenings at the George prospect, where, by using a mortar for crushing he was able to pan out more than $\$ 500$ worth of gold.

In 1934, the entire property of the Kasaan Gold Mining Company was leased to Wendelll Dawson, who made a good cleanup of the gold lost in the old mill. He then moved to the George prospect, found rich ore, and later installed a small mill. With the exception of the period during the Second World War, when he served as Lt. Commander in the Navy, Dawson operated the mine until 1950. 
Wendell Dawson did not do any mining at Harris Creek after 1950 as he and Bill Fromholzt then became occupied with Granduc copper claims in B.C. at headquarters of Le Duc River near the Alaska border. After selling Granduc, Dawson purchased a fine home outside Seattle, east of Lake Washington, but kept on prospecting during the summers. On such a trip he died May 19, 1965, in Hawthorne, Nevada, 69 years old.

Bill Fromholdzt had passed away some years before in Juneau, Alaska.

Benjamin Franklin Redman, born in 1848, in St. Louis Missouri, was well-known in this district at the beginning of the century. Besides doing a little prospecting he was quite a card player and a convincing talker. In the 1920's he lived for a number of years in the old log cabin at Hollis and later moved to Kasaan. He left Kasaan in December, 1938 on Captain Frank Murphy's seine boat "Rio Grande" for Ketchikan and the Pioneers Home in Sitka, where in died in 1940. His only son Wills Redman was a well-known prospector around Hollis. He later moved to the Westward of Alaska and it was reported that he committed suicide.

Charles Dunton is still living near Lodi, California. Dunton Street in Ketchikan is probably named after him. In 1932-33, M.K. Rodgers was associated financially with Martin Bugge in mining at Helm Bay, but was living in Colorado. Matthew Reese well-known mining engineer, born in Wales in 1877, died in Seattle, Washington, in the fall of 1948. Harold Hales, the last superintendent at Harris Creek has gone far since the mine closed down in 1929. For a number of years, Hales has been general manager of the Sherritt Gordon Mine in Manitoba, one of the largest mines in Canada. Before coming to Harris Creek as mill foreman in 1926, Hales operated the mill at the Salt Chuck Mine.

(21) The Cracker Jack Mine is located on the north side of Hollis Mountain above the Puyallup Mine and two miles in a southwesterly direction from Hollis, Prince of Wales island. This property, discovered in 1900, by James Bawden, has the outcropping of one of the most persistent quartz veins in the Ketchikan district. The vein has been traced from Portal tunnel (elevation about $300 \mathrm{feet}$ ) in a southeast direction for more than 4000 feet to the Hollis tunnel (1500 feet elevation). The vein width varies but at one surface exposure it measured 14 feet. Ore minerals are pyrite, galena, zinc blende and a black soft sulphantimony mineral. The strike of the vein is N. $25^{\circ} \mathrm{W}$ with a dip of $35^{\circ} \mathrm{S.W}$.

Practically all development was accomplished before 1907 and principal workings are the No. I and No. 2 tunnels. No. I tunnel is first a crosscut for 215 feet, then it follows the vein for about 700 feet. Two raises were driven on the vein for approximately 40 feet above the tunnel and a little ore was stoped. At 800 feet elevation, the tunnel starts at the creek that flows by the Puyallup Mine, the portal being located at the side of a waterfall which was once ingeniously utilized to aid in bringing fresh air into the tunnel. Intakes of the ventilating pipe line were placed near the falls where the draft from the falling water entered the pipeline.

Charles D. Lane, of California and Nome mining fame, had an option on the Cracker Jack property in the early days and the No. I tunnel was driven at that time with James Freeburn, another well-known Alaska mining man, as foreman. However, after the tunnel had progressed to a point past the second raise, Lane's option was cancelled. The drifting beyond that point was later done by the Brown Alaska Company, which, for 
a short time, explored the property. Tunnel No. 2, at 1050 feet elevation, is on the south side of the creek and runs as a crosscut for the first 225 feet then for 300 feet it follows the vein. A raise has been driven on the vein, and if the writer's memory is correct, this extends to the surface.

Across the creek from No. 2 tunnel about 400 feet of drifting has been done in an ore deposit tilat may be an offshoot from the main vein.

At ljou feet elevation is the Hollis tunnel which is about 400 feet in length. This tunnel enters the hill that faces Hollis Bay and it is visible from there. Cirarles D. Lane, who also operated the Puyallup Mine at that time, laid a heavy corrugatca pipeline between the Hollis tunnel and the Puyallup Mine. High grade ore was put into the pipeline and run down uy water to the Puyallup stamp mill. Parts of that pipeline were still in surorisingly good condition in the 1930's.

A very good corduroy tram-road connected Hollis with the Puyallup Mine and a similar roau branched off from the Puyallup and ascended to the Hollis tunnel. A short side road and a bridge over the creek led to the io. I tunnel. It would be difficult to use the old roads now as they are partly grown over and the corduroy is rotten. All the buildings at the Cracker Jack Mine are now down.

Besides the tunnels already referred to, sevcral shorter ones have been driven and should the price of gold be advanced to arnund $\$ b \% .02$ ser ounce, the Cracker Jack probably would be reopened because it ias a large tonnage of ore.

James Bawden, who located the mine, was a cooper by trade. He also discovered the Telegraph prospect on George Inlet, and now named the Londevan. Bawden Street in Ketchikan is named after him. He died many ycars ago in the states.

After the discovery of the Cracker Jack, Bawden interested Hollis White in the prospect but not much is rene:mbered auout this person. It is probable that Hollis Post Office was named after Hollis White. Evidently White, whose wife was reportedly a society woman, had money, for he built a big fine house near the beach and above the log cabin on Hollis Bay. Many years later the house burned down while occupied by Big Gus Detlifsen, another early-day prospector. According to Ben Leibrant, Detlifsen purposely set fire to the house - for reasons unknown. Detlifsen once was chief of police in Ketchikan. In nartnershi! with Dr. Henry Story, Detlifsen also once owned the prospect north of Harris Creek that now is known as the Dawson Mine.

At a later date, Maurice McMicken, a Seattle attorney, became interested in the Cracker Jack Mine, and after Bawden's death he obtained control of the ownership. In 1939, McMicken arrived at Hollis on his yacht "Lotus". In addition to his grown sons, he had with him James L. Cleaghorn, a mining engineer who was to direct a small crew of men in surface stripping and sampling of the lower vein. This lower vein is about 200 feet in a northwesterly direction from the vein outcroppings above No. I tunnel. Trenching across the lower vein, which has an average width of about two feet, was done for a distance of 500 feet and some samples assayed quite high. This vein can best be developed by a cross cut in an northeast direction from No. 1 tunnel. Maurice McMicken died on January 31, 1940, at the age of 79 . Since 1939, no work has been done at the mine. (James Bawden's picture hangs in Pioneer Hall, Ketchikan). 
(22) The Puyallup Mine, situated about a mile and a quarter west of Hollis on Prince of Wales Island, was discovered about 1900 by Bill Baker, a carpenter from Puyallup, Washington, while he was out hunting. Shortly afterwards, a two-thirds ownership in the prospect was sold to Robert Allison for $\$ 200.00$ and, at that time, there was supposed to be $\$ 7,000.00$ worth of ore in sight. According to old-timers, Baker knew nothing about mitiing. Allison too, was a carpenter, but from either Spokane or Okanogan, Washington, and he started the first development of the property.

In Professional Paper No. 1, of the U.S. Geological Survey, dated 1901, Alfred Brooks says of the Puyallup Mine: "The ore is chiefly iron pyrite with considerable free gold, some telluride, chalcopyrite and bornite. The vein, though small, is extraordinarily rich. The best returns from assays show three ounces of silver and $\$ 1,000.00$ in gold."

An item in the Ketchikan Mining Journal for March 15, 1902, said: "Robert Allison will go south next week to look after the shipment of the mill purchased for the Puyallup Mine near Hollis."

When installed, the mill consisted of an $\delta \times 10$ inch Blake Crusher, five 1000 pound stamps, amalgamation plates, and a concentrating table driven by a three-foot Pelton wheel. A shipment of 14 tons of ore was sent to the smelter in 1902 .

Later a surface tram-raad was built from Hollis to the mine at a reported cost of $\$ 27,000$. During the first years of operation, the mine is said to have produced close to $\$ 200,000$ but the exact sum is not known. Charles $D$. Lane must also have been able to use the mill for he sent ore from the Hollis tunnel of the Cracker Jack Mine down to the Puyallup through a pipeline.

In 1914, the mine was restaked and narned the Ready Bullion. It was then owned by Harry Webber and Angus McKenzie. At that time, a new level was opened up at a vertical depth of 170 feet from the surface, and a drift run for 400 feet on the vein. The mill runs showed a value of $\$ 30.00$ per ton. Angus McKenzie later followed logging and fishing and died about $1 ;$ years ago in Ketchikan.

The Mining and Sientific Press for June, 1914, says of the mine: "The ore bodies ure quartz in diorite and porphyry, and the vein being worked consists of 10 inches of quartz and 20 inches of altered porphyry, the latter averaging $\$ 13.00$ in gold per ton."

During the $1920^{\prime}$ s B.F. Redman had the mine staked for a few years and in 1932 , it was staked by George Gervais and named the Hope Mine. A few years later, the mine was sold to Ben Leiorant for $\$ 300.00$. It was leased about 1936 to E.W. (Doc) Brown, with whom Charles L. Smith was associated. Unable to make a go of it in a little over a year, Brown left the mine, and in 1930, the property was taken over by James Luck, Larry Erickson and Kelton Adams, all of whom made good wages for the next two years. A pocket containing about five thousand dollars was found in an old stope. E.W. (Doc) Brown, member of the - ity council and prominent in the affairs of the American Legion in Ketchikan died about 1yju.

(23) The Lucky Jim prospect, near the southwest side of the summit of Granite Mountain, has shown good values, but because of its location there has been little fevelopment. Ore minerals are pyrite, galena, malachite, and azurite. The prospect was iscovered before 1905 by James H. Nesbitt, who later acquired Fred King as a partner. Nesbitt died at the age of 65 in Hyder, Alaska, in 1938. 
(24) The Dolly Varden prospect was discovered around 1900 by Dick Fuller and is located at 1100 feet elevation, about two niles southeast of the head of Twelve Mile Arm, and three-fourths of a mile south of the main creek. A number of stringers showing azurite and malachite are exposed over a width of about 20 feet, and a length of 30 feet. They contain fair values in gold and silver. If mined over the full width, the ore would probably be too low grade to pay, and it would not be feasible to mine each stringer separately. A tunnel, about 50 feet long, has been driven in 1 imestone but failed to get underneath the ore. A short distance away there is a deep sink hole in the limestone. In 1924, the prospect was sampled by W.W. (Bill) Cole and 0liver Davis of Kasaan. They reported an $\$ 80.00$ assay return, but it is not known how or where that sample was taken. The logs of a tent frame were in fair condition in 1937.

(25) The Cuprite, or Houghton property was discovered in 1901, on the northwest slope of Jumbo Mountain at an elevation of 1500 feet, about one mile from Hetta Inlet. The Cuprite Mining Company was formed in 1906 in the State of Washington with Ed LaBounty, president; Charles E. Bedford, treasurer; J.T. Jones, manager; and A.J. Jones as superintendent. During 1906 and 1907, the development consisted of a tunnel driven at 1600 feet elevation. By 1911, the property had been taken over by Harry Brice, who performed considerable underground exploration and hauled ore over the aerial tram that connected the mine with the beach.

(26) The Jumbo copper mine, on the northwest side of Mount Jumbo, is situated about one and one-half miles from Hetta Inlet between an elevation of 500 to 2000 feet, and was discovered in 1897, by Aron Shellhouse.

Development began in 1902, and during succeeding years several tunnels were driven on the prospect. From the adit at 1700 feet elevation, an aerial tram, 8250 feet long, carried the ore to bunkers of 4000 ton capacity on the beach where a wharf with 150 foot frontage was built. The largest ore body, and also the best grade ore was on the No. $4 \mathrm{claim}$ where an irregular body of chalcopyrite ore, 30 to 40 feet wide, 120 feet long and about 140 feet deep, supplied the ore during the first years. A large tonnage was mined from other workings as well.

At about 1600 feet elevation, and joining the copper deposit on the northwest, is a body of magnetite up to 60 feet in width, forming a steep bluff that can be seen from Hetta Inlet. This body of iron is a flat laying mass between the limestone and granite, and is not expected to contain a large tonnage.

Further development of the prospect was performed by the Alaska Industrial Company, controlled by Charles $A$. Sulzer who purchased the property from Shellhouse. The mine camp and the town site of Sulzer were laid out on the north side of Hetta Inlet, about three miles from the ore bunkers at the beach.

Ore shipments to the Tyee Smelter in British Columbia began in 1907. Mining must have been going at full scale, for an old newspaper describes that in 1911 , a big Fourth of July celebration was held at Sulzer where the Declaration of Independence was read by Charles A. Sulzer. Another fine oration was delivered by Dr. A.B. Tubbs. In the athletic events, gold, silver and bronze medals were offered as prizes, and some contests had as many as thirty perscns participating. There was the 100-yard race and a shooting match between the Sulzer Gun Club and Jumbo Mine Club. In an obstacle race, 
competitors were sewed up in sacks, and the greased pole climbing created much excitement. In the nail-driving contest, eight brave ladies came forward and most of them got bruised fingers. The steamer "Meteor" being in port, a tug of war was arranged between the freignter's crew and the Jumbo miners -- the miners winning by a narrow margin. In the evening there was dancing, with music by the Sulzer orchestra, and fireworks display at dusk. (The foregoing description was obtained from the Ketchikan Miner of July 14, 1911.)

During 1914, about 1000 tons of ore was sent to the Tacoma Sinelter each month. The last year of production was probably 1918. Some work was done later, however.

Aaron Shellhouse, discoverer of the Jumbo Mine, came to Ketchikan district in 1894 and spent most of his time mining and prospecting. He also found the Lucky Strike (45), copper prospect, situated in the center of Dall island back of Grace Harbor, and the Yellowstone, (46), prospect in the vicinity of Sea 0tter Sound on the west coast of Dall Island. Shellhouse died in Ketchikan in May, 1928, at the age of 76 years.

Charles A. Sulzer must have been a good man to work for because many of his men stayed with him for years. His last trip to Alaska was believed to have been in 1934 at which time he looked quite old. Sulzer is now dead but his widow is living. Ketchikan owes much of its start to the Jumbo Mine for a qreat many of the present old timers were once employed at the mine and quite a few are still around town. Duncan Campbell, the mine foreman and gentleman liked by everyone, passed away at the age of 77 in Ketchikan on Christmas Day, 1946. B.D. Stewart, former head of the Territorial Denartment of Mines in Juneau was at the mine for some time as engineer. Chris Copstead, the genial custodian of the Miners and Merchants Bank building, once worked as a miner at the Jumbn and later was in charge of handling all freight and mail across the Portage from the West Arm of Chomley Sound to Sulzer.

Harry Townsend, Anaconda engineer, and the writer on 0ctober $14-15$ th, 1951 , went to the Jumbo Mine. Townsend did not believe that the iron denosit contained a large tonnage and as for the other part of the mine was unable to exnress an opinion regarding chances of finding more copper ore. A few years later the writer met a miner in Seattle that had worked in the Jumbo at the time the mine shut down. The miner said that when closing down (about 1920) a winze had beer. sunk about 60 feet on the right hand side going into the main tunnel. High-grade ore for the width of the winze was found on the bottom, but the small pump was unable to keep the winze dry and as the order for closing down had already been given, nothing more was done.

Will use this opportunity to express my admiration for the late Harry Townsend, Anaconda Copper Corporation exploration engineer for Alaska. I went many times with Townsend on examination trips to different mining properties and in every way he was a perfect gentleman. Coming North in the spring from Seattle, Townsend considered himself as "soft" and wishing to get in good condition, never permitted the writer to carry part of his packs when on long hikes.

In Seattle Townsend seldom used elevators as he preferred to strengthen his legs by climbing stairs. He many times climbed the stairs to his office at 1301 Hoge Building.

The Jumbo Mine holdings were recently acquired by a lumber concern of Portland, Oregon, reportedly for the large stand of timber on the ground. 
(27) The Copper Mountain mine was discovered in the fall of 1897 by Charles Reynolds and Thomas Wright. It is located on the steep mountain side about one mile north of Copper Harbor on Hetta Inlet, at from 2350 to 3500 feet elevation. The ground was purchased in 1900 by the Alaska Copper Company, and the first shipment of ore was made in 1902, when about 500 tons went to the Tacoma Smelter. This was reported to have yielded $\$ 18,000$.

By 1905, a smelter had been constructed on the beach at Copper Harbor below the mine. It consisted of a 250-ton Allis-Chalmers blast furnace, ore bins of 2500 ton capacity, and coke bins holding 1200 tons. Ore from the mine was sent to bunkers over an aerial tram 6000 feet in length. A 22-inch pipeline extended one thousand feet to Reynolds Creek conveying water for generation of 300 horsepower to operate compressors and machinery.

In 1905, J. Cuthbert Welch was the smelter superintendent and the first shipment of matte, 170 tons, was made that year. Production of the mine, had in 1906, been stepped up to 275 tons of ore per day going to the local smelter, but in the fall of that year, both the mine and smelter closed down. In 1914, the property was taken over by the Alaska Consolidated Mining and Smelting Company of Duluth, Minnesota, with N.L. Kilpatrick as manager, but evidently activities did not last long for the history of the mine and smelter from that time is dim. The president of the old Alaska Copper Company, H.W. Mellen had earlier been in charge of the Jualin Mine at Berners Bay, near Juneau, and had spent many years in Alaska. Lake Mellen, back of Copper Harbor is named after him. Reynolds and Wright were reported to have received $\$ 50,000$ when they sold the property. Both died years ago in Wrangell.

(28) The Corbin Mine discovered in February, 1905, is on tide water on the east side of Hetta Inlet, one and one-half miles north of Copper Harbor. During the following summer some ore was sent to the smelter at Copper Harbor and in the same year the property was sold to the Alaska Metals Company which started active development. A shaft was sunk to a depth of more than 100 feet and drifts were run to investigate the ore body at depth. Also, a tunnel was driven on the vein for about $210 \mathrm{feet}$. The vein of sulphide ore, from one foot to three feet in width, striking $\mathrm{N} 70^{\circ} \mathrm{W}$., and dipping $70^{\circ} \mathrm{S} . \mathrm{W}$., carried a little copper and some gold and silver.

Sometime about 1913, a shipment of ore was lying on the dock waiting to be loaded on the freighter Northland, when, perhaps due to action of the tide, the steamer moved too fast when tying up and pulled the dock with all the ore into deep water. 1913 was probably the last year of mining operations at the Corbin Mine. In the following year, however, some prospecting was carried on there by $A$. Jacobsen and $E$. Olsby.

(2y) The Copper City Mine also named the Red Wing, is situated on tidewater at the east side of Hetta Inlet and seven miles south from Copper Harbor. The discovery was made in 1898 by Captain E.E. Wyman, a native of the State of Maine, who came to Alaska in 1877.

First operations began in 1903 with ore being sacked for shipment to Tacoma Smelter, and in 1906, 140 tons were sent to the smelter. The mine was developed by an inclined shaft from which several levels had been driven on the vein. The ore body of nearly massive sulphide in the slate-greenstone country rock consisted of chalcopyrite, pyrite, sphalerite and some hematite. Besides copper, the ore at that time assayed from $\$ 3.00$ to $\$ 6.00$ in gold and silver and from six to nine per cent zinc. 
With the shaft down approximately 300 feet, the mine was operated intermittently until about 1yl0, when salt water entered through a drill hole and the mine became flooded, causing it to be abandoned. Chris Copstead, the miner who operated the machine that drilled through the bottom of Hetta Inlet, had to get away in a hurry leaving his machine and drills behind. For many years now, after quitting mining, Copstead has been a resident of Ketchikan and custodian of the Miners and Merchants Bank Building. Chris Copstead's picture is in the Pioneer Hall, Ketchikan. In 1909, C.T. Moore was in charge of the Copper City Mine.

Captain Wyman spent 1877 , his first year in Alaska, working for the Cutting Packing Company. Returning North in 1883 to Seal Bay, he managed a cannery there for three years; then in 1888 he was assistant manager of a cannery at Klawock. After leaving that place, he took up prospecting.

(30) The Khayyam Mine was discovered in logy by George McKenzie. It is located almost three miles in a southwesterly direction from the head of Mckenize Inlet, and at 2,500 feet elevation. Developments made during 1901-1907 by the Omar Mining Company, consisted of a tram-road two and one-half miles long to the terminal camp near the head of the valley, and an aerial tram one mile long connecting the mine witn the camp. A packhorse trail, still in fair condition, was also constructed along the nillside between the mine and the terminal.

The Khayyam ore body consists of lenses of i ron sulphides in a mineral zone up to 250 feet wide and more than 1000 feet in length. The Powell adit, at 2350 elevation, is 230 feet long and was driven underneath the deposit. A large tonnage of ore was stoped.

The Kimball adit, 323 feet below the Powell, was advanced about $6 / 5$ feet for the purpose of opening up the ore deposit in depth, but only near the face is the groundalittle mineralized. Examination by the U.S. Bureau of Mines shows an indicated reserve of 20,000 short tons and an inferred reserve of 64,000 short tons of pyritic material containing $1.71 \%$ copper, $0.93 \%$ zinc, $38 \%$ sulphur, $0.06 \mathrm{oz}$. gold and $0.30 \mathrm{oz}$. silver.

A grab sample, taken by the writer from an ore bucket lying on the mountain side in Septemuer, 1945, assayed $0.05 \mathrm{oz}$. in gold; $1.30 \mathrm{oz}$. silver, and $2.26 \%$ copper. When the mine was operating, six-car ore trains with a total load of 15 tons hauled the ore from the terminal to the beach where ore bunkers and a dock had been built. In 1906, operations were suspended because of mismanagement and lack of ore reserves. The following spring, H.W. Turner became the new manager and the property was reopened, but apparently not for long as little is known about the mine since that period. Once, during work at the mine, a snow-slide occurred and a few men were killed.

Fred Heckman of Ketchikan had the mine staked in 1916 and perhaps did a little work. Umar Mining Company reportedly purchased the Khayyam Mine from George McKenzie and later reports mentioned that McKenzie was living in Mexico and owned one of the richest mines south of the Rio Grande. Jacob Thomas of Kasaan is probably the only person yet living who worked for George McKenzie at the Khayyam Mine.

Mike Henigan, in later years a wealthy resident of Ketchikan, director and part owner in the Miners and Merchants Bank and of the old Beegle Packing Company, was employed as packer when the Khayyam Mine was being opened up. A heavy stove which required several men to carry was being transported when they encountered a creek bridged only by a foot log. Lacking space for footing for all the men, Henigan, a husky youngster, solved the problem by packing the stove over the creek alone. 
About one mile east of the Khayyam is the Mammoth prospect, discovered in 1901, by Tom Stevens and named the "Iron Mast." Much development was done years ago by drifting on the vein but this prospect, too, has been idle for a long time. The ore carries higher copper and gold values than that found in the Khayyam Mine.

(30) The Mammoth was staked as the "Johnlee" claim in September, 1945, and the Khayyam as the "Howbuff" by Lee Howard of the Salt Chuck Mine and the writer. Harry Townsend, Anaconda Copper Company engineer examined the Mammoth Mine in 1946 and his report was quite favorable, but because of the distance from tide water and the heavy outlay of capital needed, the property was not taken over by his company.

(31) The Moonshine Mine on the west side of South Arm, Chomley Sound, was staked around 1900 and is situated about one and one-half miles from tide water, at an elevation of 2000 feet.

Development was started in August, 1906, suspended for the winter, and again in progress from May until November, 1907. In 1907, B.C. Bacon was in charge of the work and in 1909, when William Rea was the foreman, it was reported that an 8-foot vein that assayed 1500 ounces in silver was struck.

The Moonshine vein is a well-defined fissure in limestone and schist country rock and varies in width from a few inches to several feet. Vein minerals are galena, siderite and calcite with a little sphalorite and chalcopyrite. Strike of the vein is $\mathrm{N} u 5^{\circ} \mathrm{W}$, with a vertical dip. Workings consist of several tunnels, a shaft, and a long raise to the top of the ore body, but either the ore was not there or the raise was not driven in the proper direction.

Most of the money for development was raised in Ketchikan. N.W. Sweetzer, the superintendent when the mine closed down about 1922, is now living in Rosamond, California. James Lucier, the Merchant Prince of Craig, and Archie VanWinkle, the logging operator, both worked at the Moonshine when it was being opened up in the early days. George Roberts now a resident of Ketchikan, gained his first mining experience when he was employed at the Moonshine in 1921 .

(32) The Hula Hula prospect was staked in 1899 at Kitkun Bay, by Chief Kitkun, Earnest L. Adkins and L.T. "Nigger" Watson. The chief had found a few nice quartz specimens on the beach, back of an island on the east side of the bay, about two miles from the entrance. A wide quartz vein is exposed quite a distance from the beach and is slightly mineralized on the foot wall, but too low grade to be mined. However, at that time, it was easy to sell a prospect and before long a promoter was found and the prospect sold. Adkins received $\$ 2,500$ for his share, Watson got $\$ 100$ in cash and one barrel of whiskey and Chief Kitkun got $\$ 500.00$. Adkins had contacted the buyer and for that reason he received the most money. He returned to Seattle, enrolled in the University of Washington, finally graduating as a metallurgist. Before staking the Hula Hula, Adkins had been employed by Ellick Miller in the salmon salteryat old Sunny Point, Chomley Sound. Many years later he returned to the Ketchikan district and in 1y25-26 he was assayer at the Salt Chuck Mine then operated by J.E. Chilberg. "Nigger" Watson, a negro, was a well-known character in the early days, spending most of his time out in the hills prospecting. His last years were spent around Klawock and he died in Wrangell about 1933. Chief Kitkun passed away long ago, but the name Kitkun nas not died out as a family of natives have that name and Kitkun Bay was probably, in the past, their exclusive hunting and fishing grounds. 
(32) The Croesus prospect is located about one-half mile above the head of a small bay that lies along the east shore of Kitkun Bay, about three fourths of a mile inside the entrance. It was discovered in 1892 and development commenced the next year by a company headed by J.R. MCMillan who operated a lime quarry at Roche Harbor, Puget Sound. Eugene A. Knapp was in charge of the property. Under his direction two tunnels were uriven on the vein, the lower one, at 600 feet elevation, was about 360 feet in length; the other, at 750 feet elevation has a length of 150 feet. The vein strikes north with a dip of $85^{\circ} \mathrm{E}$. and is from a few inches to four feet in width. Some rich ore was found in the upper tunnel and the best values were in a mineralized streak on the foot wall. The prospect proved disappointing, however, and all work was ended in 1902. Ore samples taken by the author from the upper tunnel in May, 1932, assayed low in gold. The country rock is greenstone schist and 1 imestone.

One or two donkey engines are standing on the hillside where they once provided steam to run the drilling machines. Some years after the shutdown, a miner was killed by an explosion while doing assessment work in one of the tunnels. Good drinking men must have populated the Croesus in the early days as a great many empty whiskey bottles were in evidence at the old cabin.

About half a mile southwesterly from the Croesus is the San Juan prospect. At 500 feet elevation a tunnel, now caved, was started near a small stream. A quartz vein about three feet wide outcrops some distance above the tunnel and a sample from a four-inch black, heavy mineralized seam on the foot wall of the vein assayed $\$ 5.00$ in gold. (1932)

(33) The Valparaiso Mine at Dolomi, on the north side of Paul Lake, was discovered either in 18y or 18y9. An Indian named Johnson and his son were hunting at the lower end of the lake where the boy was left to watch the canoe while his father tried to locate a deer. When the father returned, the boy showed him some rocks which he had found at the lake shore and Johnson later gave the rocks to Charles Guzman in Ketchikan. These proved to be quartz with much visible gold and Guzman immediately purchased the location from Johnson and staked the ground. The claim that had the best looking vein was given the name of Valparaiso by Guzman after the capitol city of Chile where he was born in 1860. He arrived in the United States in 1889.

Details of the early development are not now known except that Guzman later sold out and Charles Duntonprobably operated the mine for a while, because the remains of an arrastre, which he built, lie near the lake about half a mile west of the Valparaiso mill.

The mine was owned in 1907 by the Princeton Mining and Smelting Company which had 25 men on the payroll. By that time, a great deal of work had been done in the mine and on the Jessie claim 2500 feet to the east, where a shaft had been sunk and a hoist installed. Several shipments of high grade ore went to the smelter in 1911.

The mill, installed in 1913, consisted of five stamps and a slow speed Chilean mill. About 30 tons could be milled in 24 hours. The flow sheet was simple. The ore first went through a jaw crusher, then to the stamps, with the Chilean mill doing the final grinding. Amalgamation and gravity concentration were used but since most of the gold was "free", the values were largely recovered on the amalgamation plate. The concentrates were of low grade. 
B.A. Eardley became manager in 1914 and was in charge until the property closed down about 1920. Eardley kept a surface crew prospecting the surrounding country, and numerous shafts, tunnels, and open cuts were made. Most of the miners lived at the mine but a small town was built at Dolomi Harbor with a school house, store, assay office and a church. Being a God-fearing man, Eardley expected everyone to at tend church service. Transportation between the harbor and the mine was by means of a railroad to the lake and from there by boats and scows.

After having lain idle since about 1920, the mine was leased for several months in 1927 to Tom Stevens who made much better than wages since he had been working in the mine and knew where high grade ore was. In 1932 the Valparaiso was taken over for a while by William Paul, the lawyer, and Harry Benolkin, but their operation was not profitable. M.P. Olsen of Vancouver, B.C., obtained an option on the mine in the SDring of 1954 and after a favorable examination by John D. Galloway, a Canadian engineer, the option was transferred to Colonel E.J. Ryan, a contractor of Vancouver, B.C. The Alaska B.C. Mining Company was organized and a large sum of money spent in getting the property in shape for operation. Outside construction foreman was J.E. Amundson, and J.A. McLaughlin was to be superintendent after mining had started. About August 1, 1935, the Valparaiso was almost ready for production, ore was to be drawn from the old stopes, and ground in a new 50-ton ball mill that had been recently installed. However, all activities were suddenly stopped when Arthur J. Theis, consulting engineer for the najority stockholders of the company came to Dolomi and ordered everything closed down.

For ten years until 1945, the mine was idle. It was then taken over by Santiago Mines, Ltd. of Vancouver, B.C., with R. Crowe-Swords as managing director and during the next three years more than $\$ 200,000$ was spent in rehabilitation and new construction. Crowe-Swords had been at the Valparaiso many years before while much high grade ore was being mined. It was perhaps because of this memory, and perhaps too, the expectation that the price of gold would be raised, that he took over the mine. However, the gold valuation remained stationary and after the mine was once again ready for operation, it was not put into production. All the men were laid off and only a watchman left at the property. Later, being unable to transfer money from Canada, the company was unable to pay the watchman's wages and the mine was finally left unguarded. In 1951, it was reported that everything of value that could be carried away had been stolen from the mine.

Joinnson, father of the boy who found the Valparaiso vein on the north side of the lower end of Paul Lake, was drowned outside Dolomi. Port Johnson was probably named after him. Later at the place of discovery an inclined shaft, about 140 feet deep was sunk on the vein. Charles Guzman, the man responsible for getting the Valparaiso opened up, was considered a "live wire." Durıng his years in Ketchikan, he was very interested in mining. In 1907, Guzman was in charge of the grocery department for J.R. Heckman and Company and in 1911 he was part owner of the Indian Mine back of Hyder. He died at Taft, California in 1938.

B.A. Eardley was born in Utah in 1862 and died in Bellingham, Washington, in 1926. James Capp was also associated with the development of the mine. During John D. Galloway's examination of the Valparaiso in April, 1934, the writer assisted him in the taking of ore samples and the following are the assay values from most of the surface out croppings. 
Beauty dump averaged $\$ 13.39$ per ton.

Beauty, four foot vein averaged $\$ 19.59$ (half the values in silver).

Amazon dump, averaged $\$ 5.50$.

Three foot vein, short distance $W$ of the shaft, one sample, $\$ 12.60$.

Jessie dump averaged $\$ 9.27$.

Paul Over tunnel, 15 samples across a width of $31 / 2$ feet, averaged $\$ 13.47$.

Surface exposures of the vein, for $75 \mathrm{feet}$, between the Jessie shaft and the

Paul Over tunnel averaged $\$ 9.95$ and for 400 feet, the average was $\$ 8.35$.

East of the Paul Over tunnel three samples were taken that yielded values

of $\$ 11.20, \$ 12,95$, and $\$ 13.65$ per ton.

Discovery dump, two samples $\$ 42.07$ and $\$ 20.30$.

Three foot wide vein at Discovery, $\$ 16.70$.

(33) The Golden Fleece Mine is located on the north side of James Lake, about one and one-half miles north of Dolomi Harbor. The mine was discovered on June 6, 1899, by Arthur Knight who found gold in the soil of the hillside below outcroppings of the vein. He was born in 1861 in Worcester, Massachusetts. He lived a number of years in Ketchikan and then moved to Juneau where he died in March 1952 at 90 years of age.

A small shipment of ore was sent to the Tacoma Smelter, netting $\$ 45.00$ to the ton. An arrastre was built near a small stream one-third of a mile southwest from the discovery but it was never operated. Probably there was not enough water for power.

An examination of the newly found prospect was made in 0ctober of the same year by Russell L. Dunn, a mining engineer from Spokane, Washington. He expressed a favorable opinion of the property. Later, after capital had been acquired, two tunnels were driven and connected with a raise 400 feet in length. The upper tunnel was driven on the vein for about $200 \mathrm{feet}$. The lower tunnel started as a crosscut but its direction was wrong, and for its entire length of more than $400 \mathrm{feet}$, it encountered only barren rock.

The vein dips $40^{\circ} \mathrm{S} . \mathrm{W}$. in the raise where it was encountered halfway to the upper tunnel. In the 1920's a considerable tonnage of ore was stoped, and an extraction of $\$ 12.00$ per ton was obtained on the amalgamating plate of the small two-stamp mill. The ownership of the mine at the time this ore was milled is uncertain, but Alex Adkins owned the ground when he died, in January 1929, at the age of 67. Around 1933, the mine was leased by Mike Lane, of Moira Sound, and the vein above the upper tunnel was inined clear to the surface. Some ore was also mined from the raise. The Golden Fleece quartz claim and the mill site are patented and are now owned by the C.R. Heckman estate in Ketchikan. The mill has probably fallen down by this time.

Since none of its former operators did any crosscutting, the Golden Fleece perhaps yet has possibilities. The idea to crosscut may have occurred to those who drove the long tunnel, for the last round or two were drilled to the left where the vein should be. As the vein was found halfway up in the raise, there may be a change in the din and the vein might be picked up in a crosscut less than 50 feet from the lower tunnel.

In his report, Russell Dunn mentions assays of $\$ 13.95$ and $\$ 56.69$ from two samples of a parallel vein which was exposed on the surface near the main vein.

On the east side of Dolomi Bay, at a prominent rocky point, is a shaft which was sunk on a small seam of ore years aqo by a prospector named Admons. He also owned the Washington prospect situated about a mile from the west end of Paul Lake and on the south side of the big creek that enters the lake. 
(34) The Gladstone prospect, one of the very early locations, is situated back of Lancaster Cove on Chomley Sound and was discovered by Billy McCuen. The country rock is mostly limestone. Several veins have been found carrying pyrite and chalcopyrite with a little gold and silver. Practically all of the old workings, composed largely. of open cuts, have now caved in and no work has been done since shortly after the discovery. Billy McCuen died in 1929 in Portland, Oregon:.

(35) The Cymru Copper Mine, staked about 1899, is three-fourths of a mile from the head of North Arm, Moira Sound, and lies on the north side of Mineral Lake. In 1906, work at the property was started by a Tacoma, Washington group with J.M.Miller, president. A $40 \times 70$ foot wharf was built and a 36-inch gauge railraod constructed from the wharf to the mine, a distance of $4200 \mathrm{feet}$. Ore bunkers of 1600 ton capacity were erected at the beach. An 's H.P. gas engine was used to pull cars over the track. The first shipment of ore was made in the fall of 1906 when 662 tons went to the smelter. Returns totalled $\$ 9,370.00$ or about $\$ 14.00$ per ton at the 1906 price of copper. This grade of ore proved too low for shipping and the mine apparently closed down soon afterward for an item in the Mining and Scientific Press of Auqust, 1907, said that the Cymru Mine was to be "reopened."

Nothing is known of any further activities, except that some years later a shipment of ore was supposed to have been made by Axel Carlson, now foreman for the Ketchikan Public Ltilities. In September, 1928, the writer found nothing left of either the wharf or the ore bunkers. A heavy growth of trees and brush made walking on the old right of way difficult and the ties had rotted away, leaving the rails hanging over depressions in the ground. Only one building was still standing at the mine, but the head frame over one of the two shafts appeared to be in good condition.

(36) The Blue Bird prospect is at 1500 feet elevation on the south side of North Arm, Moira Sound, about one and one-half miles from the cove where the Starr-Collinson cannery used to be. It is situated near a small lake on top of the mountain ridge. It was staked in 1301 by John A. Westlake, who was born in Dublin, Ireland, in 1849, and who was a well-known old time prospector who spent much time in that section of Prince of Wales Island.

In the early days a shaft was sunk 40 feet in mineralized schist, but since the vein was quite flat, it is believed that the shaft passed through the vein and for that reason, the vein was "lost". Ore minerals are qalena, zinc blende, pyrite and free gold in a gangue of quartz and graphite. High assays have been had from the vein, but not enough work has been done to prove the ground. The late Richard Nucholls, when at one time panning dirt from the surface of the vein, obtained 25 cents worth of gold in the pan.

A number of people in Ketchikan financed what work was done at the prospect, and of them, perhaps the only one yet living is Gus Pruell of Pruell's Jewelry Store. George Morrison of Tongass Haruware Store, now dead also spent money on the Blue Bird and he aways express his opinion tnat the ground was worth further development.

(37) The Gold Stream Mine on Tongass Narrows, on the east side of Gravina Island and three miles south of Ketchikan, was discovered December 15, 1902, and staked January 2, 1503, by i)to Miller, and L.G. Phillips. On March 3, 1903, the prospect was 
leased by Charles D. Lane and development was immediately started by him. Later a five stamp mill was installed by Lane, but being used to large tonnage mines, the Gold Stream proved too small for Lane and he left the property.

In 1906 the mine was operated by Irving Consolidated Mining Company, owned by Otto Miller, George Irving and Harry Brice. High grade ore was shipped to the Tyee smelter in British Columbia, but the low grade was milled, giving a recovery of about $\$ 8.00$ per ton.

The late Bill Dalton, with a partner, once operated the Gold Stream on a lease and they made an average of $\$ 14.00$ per day. The mine has now lain idle for many years with the exception of one and one-half years in the 1930's when L.L. Winnie ground-sluiced part of the old dump and recovered enough gold to permit him to retire to a life of leisure on his yacht in Thomas Basin, Ketchikan, where he died May 29, 1952, 80 years old.

(38) The Schoenbar Mine, a short distance from the Ketchikan ball park, was probably discovered while the city was first being settled. It was first named the Laskawanda, but it later acquired its present name from Colonel John Schoenbar. A newspaper item in the spring of 1902 says that "work on the Laskawanda has been suspended for some unexplained reason but a couple of men are still engaged in work necessary to making good the title to the water claimed for the operation of the mill and mine." (The property had no mill). Two shafts had been sunk and in 1906, one of them was 05 feet deep. The property has a large body of low grade ore carrying copper, gold and silver, but by 1906, practically all development had stopped. In that year, Colonel Schoenbar was sent to Boston by the Chamber of Commerce for the purpose of advertising the natural resources of Ketchikan to New Englanders.

In 1933 Charles L. Smith made a deal with the Home Land Company, present owners of the property, for the development of the ground. In place of underground exploration, however, Smith had the idea tnat the oxidized ore on the surface could be cyanided without fine grinding. That year fell in the middle of the depression, a time when fishing hardly paid expenses and many people were mining-minded for which reason the smoothtalking Smith obtained both credit in the stores and labor for the mine on glib promises of payment as soon as the gold bricks were sent to the U.S. Mint. Smith probably had made some study of mining; there was not a rock that he could not identify at a glance. Naturally, Smith was considered by many as the greatest mining man that ever came to Alaska. Several large tanks were erected and surface material treated, but to save cyanide. the solution was often too weak to kill flies. As could be expected, the cyanide resoveryprocess failed. However, Smith had received the benefit of about one year's free bodrd and clothing, which is probably all he expected.

(39) The Lon-de-Van prospect, on the north side of George Inlet and a short distance from the cannery, was discovered about 1900 by James Bawden and named the Telegraph prospect. At an elevation of about 1000 feet, six quartz veins have been found and early reports gave a value of $\$ 12.00$ per ton in gold and silver. The ore also carries zinc and lead.

In 1908, underground development was started by driving a crosscut tunnel from the beach. The tunnel is 2,050 feet long and cuts a downward extension of the veins at a depth of about 1000 feet below the outcropping. From the crosscut about 1800 feet was 
drifted on the veins to the south and 500 feet to the north. Because of bad air in the crosscut, no underground examination has been made since the development work stopped many years ago. The property is now held by Elmer Johnson and Kenneth Pond of Ketchikan.

(40) The Sea Level Mine, on the east side of Thorne Arm was discovered before 1900. In 1902, at 250 feet elevation, a shaft was sunk to a depth of 125 feet with drifts on the vein at the 50 and 125 foot levels. In that year, total underground workings amounted to 1200 feet. The Mining Journal in Ketchikan, dated March 15, 1902, says, "At the Sea Level the pipeline from Gokachin Creek, one mile long, has been installed and the steamer Alki orought two complete batteries of stamps, one skip, six Pelton water wheels, 150 joints of $26,24,22$, and 20-inch pipe. The S/S Topeka on her last trip lanced 71 joints of pipe, an air compressor and four power drills.' Also the paper mentions a Mr. Hammond, as directing the setting up of machinery and a Mr. Kigby as superintendent.

A 30 stamp mill was set up and in operation at the beach that year, but after about a year all mining stopped and the property has been idle since that $t i m e$. Eu. C. Morse, a young engineer, formerly employed at the Sea Level Mine, wrote to the writer in 1326 saying that operation of the property had failed because not enough ore had been developed before milling commenced. Further extracts from that letter are quoted below, in detail:

"........ The only thing in my judgment that was wrong with it was the loading up.......with too complete a plant without having carried out the preliminary development program that was originally contemplated. It was not possible to get sufficient ore for that thirty stamp mill from the small amount of openings that were there at the time. I believe if they had only had a ten stamp mill with correspondingly smaller equipment as well as smaller po:yer devalopment they could probably have made a profit even with the little development they had and kept it going until they got more ground developed and more plant built.

"We unquestionably worked at least two and a half times as much dike matter along with the vein matter as we should nave worked. The one level that was opened was pretty well stoped out so that unless anotner ore shoot could be found at either end of the old stopes some additional sinking and blocking out of ore would be necessary Defore there would be very much feed for a mill obtainable. One great trouble in my time was that their drills were too heavy and they stoped an unnecessarily wide area as well as stopiny a good deal of vein matter that laid in vetween the ore shoots.

"In the region around the shaft considerable coarse free gold was found. I took out $\$ 7,40 J .00$ in sinking the first forty feet. Then the management decided to back up and change it into a vertical snaft and of course we quit following the vein. But when we crosscut into the vein again, we found this same coarse gold and the coarse gold was present as far down as we went. When we got away from the shaft region, however, the most of the gold was mechanically associated with iron sulphides much as it is in the country around Juneau.

"I believe that if the Sea Level were opened in miner-like fashion on not too extravagent a scale, the mine opening somewhat preceeding the matter of milling plant, it would stand a very good chance of proving to be a winner. In my time any values in excess of $\$ 2$. bu per ton could be considered a profit. Under operating conditions 
that would be probable now you would no doubt have to have $\$ 4.00$ per ton ore or more to pay a profit because it would be smaller scale operation and the cost of producing a dollar in gold has been at least $25 \%$ higher ever since the war. If the ore body is as good below the present level as it was where we worked, you should be able to develop ore tilat would make that kind of feed for a ten stamp inill.

"There is one adjoining claim and two other attractive claims in that vicinity upon which considerable gold has been found since I left that country. There was also one stringer that produced considerable high grade free cold ore about a quarter of a mile from the mouth of Gotatcheen Creek. As near as I can remember that was located about $f$ ifteen hundred feet east of the Sea Level shaft. If you should decide to start work on the Sea Level, before any considerable amount of money is spent, those claiins should at least be covered by options.

"I was reliably informed that the Jackling interests did some work on those claims in 1314 and that it is probable that a deal would have gone through if conditions incident to wartime hadn't made all kinds of gold mining ventures unattractive.

$" \ldots \ldots \ldots \ldots \ldots \ldots \ldots \ldots \ldots \ldots \ldots \ldots \ldots$

Ed. C. Morse has now Dassed away, but in 1927 he was superintendent of Sunset Copper Mine near Index, Washington.

(40) The Goo Goo prospect was staked in 1905 by Richard Nuckolls and Gundar Nyqard. It is locateo about 15 ú feet from Thorne Arm and about the same distance north of Gokacnin Creek. At the place of discovery the vein was 22 feet wide. In addition to free gold, the vein contained pyrite, sphalerite and nalena. A few small dockets of free gold were taken out later.

About 1934, the Goo Goo and a few adjoining claims were taken over by the Evis Mining Company which diamond drilled the Eoo foo disclosing good ore at depth. Anparently the loo Goo vein continues through the Mujestic, the ajjoining claim towara the beach, for a tunnel was started at tide water ana ariven on the vein for the whole distance into the Goo boo ground. A small filot mill was crected and ore milled for the nurnose of getting an estinate of the average value of the ore before a bigger mill was installed. The long adit had opened uo d large tonnage of ore and inuicated the probability that more mignt be encountered. However, the jrade of nre inilleci proved a little ton low for ;rofitable operation and by 1,37, all work had stopneci.

After the Evis Company nad lougnt the ron C.oo claims for about $\$ 2 \%$, was filed by Lr. L.E. vickinsun against huckolls and iygara, claimina that both of them add been grubstaked iy $11, \ldots$ anu the judgment of the court upthela bickinson's request for une-tnird of the rurchase p.rice. The Evis Company also, rurchasas the adjoining Sea

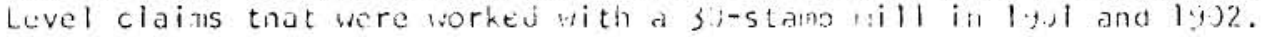

(i,1) Lat Island is south of ketchiran, not far from lary Island Liahtinuse. In

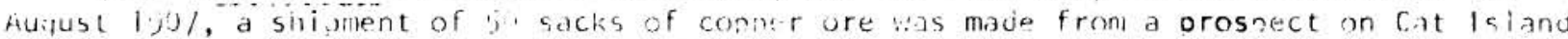
ny P.L. Peterson. He was alsu interestes in ninini claitis on soca de cuacira. 
(42) Two properties on Miclean Arm have had a good deal of development, but only one of them has been brought into nroduction. A copper prospect discovered years ago by Marsh lckes, is about three and one-half miles inside the Arm on the south side, and one-izalf mile back from warehouse Cove. Several tunnels were driven at this prospect and some inigh grade ore found, but it appears to have been generally overlooked. Owners are ur. W.E. Peterson and Axel Carlson of Ketchikan.

Fiarsh Ickes, a much respected old timer, died in lowa in 1934 at the age of $\mathcal{6} 2$ years.

(42) Tlue Nielson : Tift Mine, on the north side, a short distance inside McLean Arm, was ciscovered in 193 , by 0 to ivelson and $N . C$. Tift, salmon trollers. The prospect turned out to be a small bonanza because of its high grade ore and location at tide water. Some snipments which were sent to the smelter went better than $\$ 100.00$ a ton. After being operated by the owners for a winile, the property was taken over by Anaconda Copper Company, but because of difficulties ivith the owners with regard to terms, Anaconda relinquished the option and cancelled the planned development work.

(43) Very little is known about the early history of the McLeod Bay prospect on vall Island except that it was discovered about 1900 by William D. McLeod. A considerable sum of money must have been raised, however, to pay the cost of the development work aone after the turn of the century. The prospect is located on the south side of Mcleod bay at about 500 feet elevation. The vein has been traced by open cuts for about is 00 feet. About 100 feet vertically below the vein, or 275 feet measured along the surface slope, a crosscut tunnel has been driven. Judging from the size of the dump it scems likely that arifts were also run on the vein. The portal is now caved in a slide. About 600 feet west of the portal, there is another, but shorter, tunnel that is now nearly covered by slide rock. The vein in this slide is about 2 feet wide and carried good gold values, but it will be difficult to open up because of the tendency to cave. About 20 u feet west of the slide a short adit cuts a similar vein, but this vein nas not been found in anv open cut. The writer trenched across the vein in 1947 over a distance of $500 \mathrm{feet}$ and proved the vein to average six feet in width with values close to $\$ 4.00$ per ton. About 700 feet from tide water, at an elevation of 30 feet, there is an asit 175 feet in length that was probably startea as a crosscut tunnel with the ooject of cutting the quartz vein at depth. Most of the hillside between the vein and the beach is a schist formation imoregnated with sulphides. Some of this schist contains yood values, tut it is doubtful that the grade would permit mining on a larqe scale.

William U. Mcleod was a missionary stationed in the Haida Village of Howkan, on Long Island, in the 1000's. In aduition to the prospect at McLeod Bay, he also found a ricn pocket on the south side of Flat, or Blanket Island. It is located near the shore of Sukkwan Island abcut five miles northwesterly from Lime Point. The rich outcrop was found on the beach, but too much powder was used and most of the gold was blasted into the ivater. Hovever, McLeod is supposed to have recovered a feiw thousand dollars. Incleod bay was named after him. The late Hal fould, a miner and prospector during tile time mining was booming, is believel to alsn have had this McLend prospect stakea. 
(44) The Virginia prospect, located one and one-half miles westerly from the head of McLeod bay, was discovered by old man Volk, a German who lived on Volk Harbor, on the outside of Dall Island.

The prospect, at an elevation of about 300 feet, is an open muskeg country. The vein can be traced for more than 2000 feet striking northwest and southeast along the creek that enters Volk Harbor from the north. Its width is as great as ten feet. Open cuts and two shallow shafts have been sunk on the vein. A sample taken by the writer, in September 1943, from the dump of the northivest shaft, on the creek bank, assayed a little more than $\$ 21.00$ per ton. Samples from other parts of the vein were lower in value. 